\title{
Animal welfare research - progress to date and future prospects
}

\author{
L. Boyle ${ }^{1}$, M. Conneely ${ }^{1}$, E. Kennedy ${ }^{1}$, N. O'Connell ${ }^{2}$, K. O'Driscoll ${ }^{1}$, B. Earley ${ }^{3 \dagger}$ \\ ${ }^{1}$ Teagasc, Animal \& Grassland Research and Innovation Centre (AGRIC), Moorepark, Fermoy, Co. Cork, P61 C996, Ireland \\ ${ }^{2}$ School of Biological Sciences, Queens University Belfast, 97 Lisburn Road, Medical Biology Centre, BT9 7BL Belfast, United Kingdom \\ ${ }^{3}$ Teagasc, Animal \& Grassland Research and Innovation Centre (AGRIC), Grange, Dunsany, Co. Meath, C15 PW93, Ireland
}

Abstract

The welfare status of an animal is dependent on its ability to cope and exist in harmony with its environment, such that good physical and psychological health is maintained. Improving animal welfare is an increasingly important aspect of livestock production systems due, in a large extent, to increased consumer concerns about animal production practices. Animal welfare is an integrated part of quality assurance programmes for sustainable animal production, considering that welfare, health, management, economy, consumer acceptance and environmental impact are interdependent. The major welfare concerns in the livestock industry in recent years relate to the rearing and management of dairy calves, the welfare of the dairy cow, effect of husbandry management procedures on the welfare of beef cattle, rearing of sows in gestation and farrowing crates, and the broiler (meat) chicken sector. The paper will focus on scientific research underpinning these welfare concerns, with a particular focus on research conducted on the island of Ireland.

Keywords

Animal welfare $\cdot$ beef $\bullet$ dairy $\cdot$ pig $\bullet$ poultry $\cdot$ welfare assessment

\section{Introduction}

In Ireland, the proportion of respondents to an European Union (EU) survey who believe the welfare of farmed animals should be better protected than it is now increased by $22 \%$ from 2006 to $80 \%$ in 2016 (European Commission, 2016a, 2016b, 2016c, 2016d). Indeed, it is now widely accepted that as sentient beings with a capacity to feel pain and experience emotions, our farmed animals deserve to experience a life that is worth living (Mellor, 2016). During the last century, dairy production systems expanded and intensified giving rise to growing public concerns surrounding the welfare of dairy animals (Barkema et al., 2015; Wolf et al., 2016; Mee \& Boyle, 2020). There is growing evidence that such expansion is associated with challenges to the welfare of dairy animals on farm (Osawe et al., 2021). Thus, the issue of dairy calf and cow welfare is becoming increasingly present in research agendas in Ireland, and internationally. Beef cattle production within the EU, and in Ireland in particular, is less intensive than areas of animal agriculture associated with the greatest welfare concerns such as pig and poultry production. Nonetheless, there are aspects of beef cattle production such as the castration, weaning, transport and housing of beef cattle which have the potential to cause stress, pain and injury if not managed correctly. In Ireland, commercial pig farming is a small, intensive industry, with nearly all pigs bred and reared indoors on slatted or semi-slatted systems. According to the 2020 pig census, 284 pig farms contain $96 \%$ of the 1.7 million pigs in the country (DAFM, 2020). Indeed the average size of commercial herds is among the largest in Europe. Volatility and high prices of cereals and compound feeds, a relatively low pig price and a high level of farm credit mean that Irish pig farmers are particularly vulnerable to economic pressures. This contributed to the need to achieve economies of scale in Ireland and internationally, and management of pig farms in a way that is as resource and labour efficient as the law allows. The broiler (meat) chicken sector is undergoing a period of welfare-driven transformation. Over 100 million broiler chickens are produced per year in Ireland ${ }^{1}$, and this sector is

${ }^{1}$ https://www.teagasc.ie/rural-economy/rural-development/diversification/broiler-production/. 
of major importance globally with over 100 million tonnes of chicken meat produced annually. In fact, the Organisation for Economic Co-operation and Development (OECD) figures for 2020 indicate average global consumption levels (kg/capita) of 14.9 for poultry meat, 10.7 for pork, 6.4 for beef and veal and 1.8 for sheep meat. More broiler chickens are farmed than any other type of animal (FAO, 2019), which suggests that more individuals are impacted by changes to on-farm welfare standards than with any other livestock enterprise.

\section{Animal welfare assessment}

Over the last decades, the welfare of farm animals has become increasingly important, both for the general public and for the scientific community. National (e.g. Department of Agriculture, Food and the Marine (DAFM), Animal Health and Welfare Act 2013) and EU regulations (Simonin \& Gavinelli, 2019) or international codes of welfare (World Organisation for Animal Health [OIE]) increasingly include provisions that address the welfare management of livestock. Animal welfare is not a new concept and was defined by Brambell since 1965. The original Brambell Five Freedoms were simply expressed around concepts "stand up, lie down, turn around, stretch, flap wings". Subsequently, the five freedoms were developed into a useful framework to identify welfare components and problems (Botreau et al., 2007, 2009; Velarde \& Dalmau, 2012). However, due to the general nature of these ideal states, there were limitations to the use of the five freedoms to describe animal welfare (Botreau et al., 2007).

The Welfare Quality project was the largest European project concerning animal welfare (Blokhuis et al., 2010). It was designed to develop European standards for welfare assessment on farms (Blokhuis et al., 2010). The Welfare Quality project re-examined the original concepts of the "Five Freedoms" and developed and extended them into Welfare Quality Assessment Protocols (Botreau et al., 2007; Blokhuis et al., 2010).

The emotions that animals experience are a key component of animal welfare and the focus on emotions as an element of positive animal welfare is well recognised (Lawrence et al., 2019). Animal-based indicators provide the best means of assessing welfare, as they directly reflect the experience of the animal within its environment (Whay et al., 2003). It is now acknowledged that welfare assessment protocols should also include measurements of the affective state of the animal (i.e. how it feels) and assess its ability to have positive experiences, as it is now accepted that good welfare does not simply mean the avoidance of negative experiences, but must also include positive ones (Yeates \& Main, 2008). The five domains model (Beausoleil \& Mellor, 2015; Mellor \& Beausoleil, 2015; Mellor, 2016) assess animal welfare under the following five criteria: nutrition, environment, health, behaviour and mental state. The three orientations approach (Fraser et al., 1997; Webster et al., 2015; Mellor, 2016) assess animal welfare under three criteria: biological functioning, affective state (feelings and emotions) and natural living. Affective states are one of the three commonly discussed components of animal welfare (Mendl et al., 2009, 2010; Mendl \& Paul, 2020), the remaining two being natural living and physical health (Fraser et al., 1997).

\section{Dairy calf welfare}

Young calves are particularly vulnerable to poor health and static morbidity and mortality rates across the dairy industry worldwide suggest this is an area where animal welfare must be improved (Mee, 2020). In Ireland, dairy bull calves or beef breed heifers are most typically sold from the farm preweaning and they most commonly leave the dairy farm within the first 2-4 wk of life (>75\%; Barry et al., 2020). Dairy breed heifer calves stay on the farm and are reared as replacements for the dairy herd. The optimal rearing of female replacement calves is a fundamental component of the future success of dairy herds (Roche et al., 2015). For example, if replacement heifers are reared with technically proficient practices, which implement high standards of animal welfare, there is lower morbidity and mortality.

Technical proficiency in calf rearing involves a number of areas, pre-weaning nutrition of calves (e.g. colostrum, transition milk and milk [whole milk and milk replacer] feeding as well as concentrate feeding) and management practices (e.g. environmental conditions, weaning procedures) as these can have a pronounced effect on physiological health, welfare, behaviour and mortality of the calves (Miller-Cushon et al., 2013; Webb et al. , 2013; Leruste et al., 2014; Sutherland et al., 2014) and can influence their future performance (Soberon et al., 2012; Gelsinger et al., 2016).

To provide protection from infectious diseases in early life, neonatal calves are dependent on the passive transfer of antibodies from colostrum (Godden, 2008). Recent research focused on establishing the quality of colostrum in the Irish national dairy herd (Conneely et al., 2013; Barry et al., 2019). Good-quality colostrum is defined as that which has an immunoglobulin $\mathrm{G}(\mathrm{lgG})$ content $>50 \mathrm{mg} / \mathrm{mL}$; in general, colostrum from Irish dairy cows is of high quality $(>85 \mathrm{mg} / \mathrm{mL}$ IgG; Conneely et al., 2013; Barry et al., 2019). However, there is considerable variation both within and between herds indicating the requirement to test colostrum quality before feeding, a practice currently rarely undertaken (Barry et al., 2019). Some of the factors found to affect the quality of colostrum of Irish dairy herds include parity, month of calving, time between calving and colostrum collection and weight of colostrum (kg) (Conneely et al., 2013). 
Due to the compactness of the calving season, over $90 \%$ of farmers report storing colostrum for use at a later time; almost one-quarter of farmers are storing it at room temperature (Barry et al., 2019), a practice which leads to exponential growth of bacteria which can inhibit IgG absorption by the calf (Cummins et al., 2017). This can have negative consequences on calf health.

As there is considerable variation in cow type within the Irish dairy herd (Coffey et al., 2016; O'Sullivan et al., 2020) and a resultant difference in calf birth weight, it necessitated the examination of colostrum feeding strategies based on calf birth weight. The results showed that passive transfer was maximised when calves were fed $8.5 \%$ of their birth bodyweight in high-quality ( $>50 \mathrm{mg} / \mathrm{mL} \mathrm{lgG}$ ) colostrum, when compared to either $7 \%$ or $10 \%$ of their birth bodyweight (Conneely et al., 2014a, 2014b). This research also showed the benefits of improved calf health when transition milk is fed for at least four feeds after the initial colostrum feed (Conneely et al., 2014a).

Following colostrum and transition milk feeding and in order for calves to grow at an appropriate rate, they need adequate nutrition (milk feeding volumes); traditionally, Irish dairy farmers offered $4 \mathrm{~L}$ of milk to each calf daily. This volume is insufficient, particularly in early life when the calf's rumen is not fully developed and cannot adequately utilise nutrients from concentrate (Lorenz, 2021). Feeding calves $15 \%$ of their birth bodyweight in high-quality milk increases weight gain during the pre-weaning period and ensures that the nutritional requirements of the calf are satisfied (Conneely et al., 2014b), while also ensuring they express normal behaviour (Sinnott et al., 2021).

Clearly optimal practices for colostrum feeding and artificial rearing are required for all calves in the dairy herd. However, there is ample research to indicate deficiencies in the nutritional and housing management of male dairy calves worldwide (Boyle \& Mee, 2021). This is because of their lower economic value (Marquou et al., 2019), exacerbated in recent years by breeding practices (Kelly et al., 2020). Herd expansion is also associated with an increased likelihood of shipping calves surplus to the needs of the dairy herd (mostly males) abroad and of early slaughter (Osawe et al., 2021) which are contentious practices (Haskell, 2020). Recent research outlines ways to protect the welfare of such animals including incorporation of animal-based outcomes relevant to health and welfare at calf slaughter, greater use of sexed semen and more focused breeding plans as well as expanding calf housing facilities (Balzani et al., 2021; Mee \& Boyle, 2021; Osawe et al., 2021). However, future research is essential to investigate the calf transport conditions. This includes the appropriate movement age to ensure their health is not compromised, feeding strategies immediately prior to transport, mixing of herds both during and after transport and management systems at the destination farm.

Any calf management system, regardless of whether for replacement heifer rearing, beef production or a combination of both, should ensure calf health and welfare are not compromised. Welfare assessment protocols can be a key tool in protecting the welfare of calves on dairy farms. To this end, a reliable, feasible and time-efficient welfare assessment protocol, for male and female dairy calves, during milk feeding and weaning was developed (Barry et al., 2019). Although there are a number of welfare assessment protocols available (e.g. the Welfare Quality ${ }^{\circledR}$ project), one did not exist which combined the three factors of animalbased data (e.g. physiological health parameters, general appearance assessment and behavioural measurements), routinely collected data and resource-based indicators (management and environment). Specifically, there were no available welfare assessment protocols for dairy heifer and bull calves, to give an overview of all calves but also to allow for differentiation of the sexes. Figure 1 details the three main areas of the welfare assessment protocol which involved (i) management practices, ascertained via one-to-one survey with calf manager, (ii) independent animal assessment, and (iii) evaluation of environmental conditions (Barry et al., 2019).

\section{Early dairy cow-calf separation}

The importance placed on the ability of dairy cows to express their natural behaviour is also evidenced in the growing body of research accumulating in the area of cow-calf contact rearing systems. The dairy industry and the public are increasingly interested in management systems that allow cow-calf contact (Sirovnik et al., 2020). The cow is highly motivated to visit her calf (Johnsen et al., 2021), indeed will push up to $90 \mathrm{~kg}$ to access it (Wenker et al., 2020). There is currently no evidence to indicate early separation is beneficial to cow health (Beaver et al., 2019). In fact, systems which allow contact between the dam and the calf reduce the risk of mastitis in dairy cows (Beaver et al., 2019).

Newborn dairy calves are usually permanently separated from their dams within a few hours after birth. This is a typical practice in dairy farming and applies to conventional production systems (Kennedy et al., 2014). Heretofore, best practice was to remove the calf from the cow immediately postcalving for biosecurity reasons (Lorenz et al., 2011) and to promote greater health (e.g. minimise risk of Johne's disease; Kennedy et al., 2014). However, consumers are currently questioning this practice of immediate removal in terms of the welfare implications for both the cow and calf. While a number of studies are being undertaken internationally examining the effect of retaining the calf with its mother post-calving (Beaver et al., 2019), pasture-based systems of dairy production, such as those that predominate in Ireland and New Zealand, pose a 


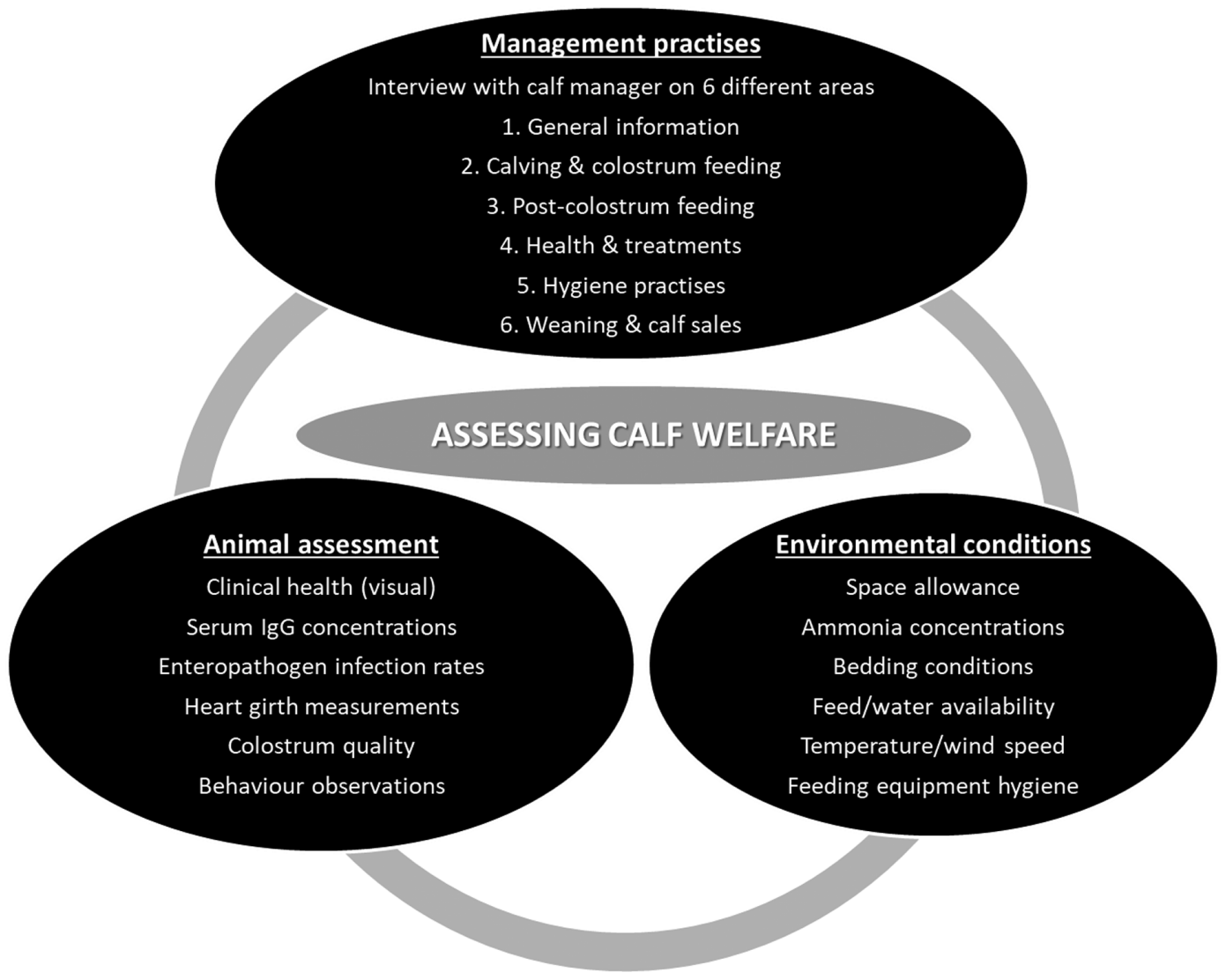

Figure 1. An overview of the components involved in assessing calf welfare. Management and environmental factors affect the animals. Animal welfare can be best assessed by using animal-based measures, while measures on management and environment can help to find factors affecting animal welfare. IgG, immunoglobulin $\mathrm{G}$.

unique problem. These systems are characterised by compact seasonal calving patterns and by their reliance on pasture in the diet which necessitates the early turnout of dairy cows to pasture (Kennedy et al., 2005). Future work will ascertain the effects of retaining the calf with its mother until weaning on animal welfare, productivity and on the implications for workload on the farmer in a pasture-based scenario (One Welfare; García Pinillos et al., 2016). Recommendations for future calf management will be dependent on these results.

\section{Dairy cow welfare}

Much research on dairy cow welfare in Ireland focused on the issue of pasture access for dairy cows. Pasture-based systems are viewed as superior to housed systems for cows, as they allow cows to perform their natural grazing behaviour, which is a high-priority activity for them (Krohn, 1994). Pasture access also promotes more synchronous herd lying behaviour, as well as increasing cow comfort which facilitates longer lying bouts and overnight lying durations (Crump et al., 2019). However, lying duration at pasture is dependent on grass allowance; cows on a low feed allowance spend less time lying (O'Driscoll et al., 2019). Furthermore, access to pasture may lead to more positive state of mind in dairy cows (Crump et al., 2021). Grazing also benefits health, sometimes reducing lameness (Olmos et al., 2009a) and mastitis (Fontaneli et al., 2005) and improving reproductive health (Olmos et al., 2009b). However, cows at pasture may be more likely to suffer metabolic/nutritional stress (Olmos et al., 2009b), and may be at increased risk of parasitism and other health problems including grass tetany, ketosis and subacute ruminal acidosis (EFSA, 2009). Recent Irish research demonstrated that cows had greater skin damage to the head and neck during the housed period (Crossley et al., 2021) but more nasal discharge during the grazing season. Therefore, it should not be assumed that welfare is automatically better when cows are outdoors. The ideal 
situation would allow the cow to choose, as environmental conditions may alter her preference (Legrand et al., 2009), although, in general, cows show an overall preference for pasture (Arnott et al., 2017). Management of the system (in terms of animal husbandry) may be as important as the type of production system (confinement, pasture-based or hybrid) in ensuring good dairy cow welfare (Mee \& Boyle, 2020).

Irish research shows that increased comfort levels in cubicles during the winter housing period were associated with improved claw health in heifers, mediated through an increase in lying time (Leonard et al., 1994). Overcrowding reduced lying time, with negative consequences on claw health (Leonard et al., 1996a, 1996b). Cows prefer to stand on softer surfaces; when the passageway and feed face were covered in rubber flooring, cows spent more time standing at the feed face, whereas cows on a concrete floor spent more time in the cubicles (Boyle et al., 2007). In Ireland, cows must be managed off pasture during the winter months due to low grass growth and the risk of damage to the ground conditions. This period of confinement can last anywhere between 3 and $6 \mathrm{mo}$, and traditionally cows were kept in cubicle houses. However, these are expensive to build, so alternatives to indoor housing of cows were also examined. Keeping cows on out-wintering pads during the dry period did not negatively impact lameness and hoof health (O'Driscoll et al., 2008a; 2008b), or mastitis incidence (O'Driscoll et al., $2008 \mathrm{~b})$, and in fact, conferred welfare benefits by allowing more synchronised lying behaviours (O'Driscoll et al., 2008c). As cows are herd animals, synchrony of lying behaviour is an internally motivated natural behavioural characteristic and is considered reflective of natural behaviour patterns and, as such, good welfare (Crump et al., 2019). Out-wintering pads also provided welfare benefits to yearling heifers, reducing limb lesions and increasing comfort, social and play behaviours (Boyle et al., 2008). Research investigating the effect of milking frequency on dairy cow welfare concluded that in general once-a-day milking resulted in improved hoof health and mobility, by allowing increased time for cows to lie (O'Driscoll et al., 2010, 2015), and did not negatively impact cow comfort (O'Driscoll et al., 2011). However, once-a-day milking reduces phagocytic activity of polymorphonuclear neutrophils (PMNs) and monocytes, and would be detrimental for the immune system in high-yielding dairy cows during early lactation (Llamas Moya et al., 2008a).

It is increasingly recognised that the human-animal relationship is a key factor influencing the welfare of dairy cows (Hemsworth \& Coleman, 2011). Negative tactile interactions such as slapping cause cows to become fearful, which results in avoidance of humans, and may reduce milk yield (Breuer et al., 2000). Conversely, an improved farmercow relationship can reduce stress indicators (Ebinghaus et al., 2020) and fear, and improve yield (Hemsworth et al.,
2002). Fearful responses increased with time spent at grass and decreased with time spent indoors (Crossley et al., 2021), suggesting that as cows are less exposed to humans they become less comfortable around them. The impact on their well-being is unclear, however.

Affective state is defined as an umbrella term that encompasses both emotions and mood (Kremer et al., 2020), and in dairy cows, it may be assessed by measuring spontaneous physiological responses (including cortisol, heart rate variability, eye/nose temperature and eye white) and spontaneous behavioural responses (escape and wound directed behaviours, vocalisations and facial expressions). Affective state can also be evaluated using preference tests, approach/avoidance tests and motivation tests (Ede et al., 2019). Potential indicators of positive welfare include comfort index, duration of lying bout time and duration, exploration/ chewing of branches, licking while standing on three legs, rumination, synchronisation of behaviours, allo-grooming and avoidance of distance (Mattielo et al., 2019).

Pain, because it is one of the most unpleasant negative affective states, is of particular importance, it causes the most public concern (Weary et al., 2006) and is widely recognised as an important issue for dairy cow welfare. Pain can result from many issues, including lameness, mastitis, dystocia and tail docking and disbudding. Tail docking is not legal in Ireland, yet Crossley et al. (2021) demonstrated that cows with docked tails were present on almost $65 \%$ of farms visited, indicating that this is nonetheless a significant issue. Research to identify (Gleerup et al., 2015) and manage pain in dairy cows (Stillwell et al., 2014, 2019) is ongoing.

\section{Future challenges}

In response to policy changes which focus on driving milk production in the absence of quota constraints, herd sizes are increasing (Kelly et al., 2020) and grazing practices are becoming more intensive (Roche et al., 2017), which has potential impacts for the behaviour and welfare of cows (Boyle et al., 2015). Significant scientific advancements greatly increased our understanding of what constitutes good welfare for dairy cows and how best to assess it. As a result, we are better equipped to improve the welfare of the dairy cows in our care, which is vital if the Irish dairy sector is to respond to future challenges.

The European Green deal, which aims to overcome the threat of climate change and environmental degradation by making the economy of the EU sustainable, targets a $55 \%$ reduction in greenhouse gas emissions by 2030 (European Commission, $2020 \mathrm{a}$ ), and a $50 \%$ reduction in the sales of antimicrobials for farm animals (European Commission, 2020b). Improving the welfare of dairy cows can contribute to these goals. Cows experiencing good welfare are likely to be less stressed and consequently less susceptible to disease (Chrousos, 2009; 
von Keyserlingk et al., 2009), and require less antimicrobial treatment as a result. Healthy animals are also likely to remain in the herd for longer (De Vries \& Marcondes, 2020). Extending the dairy cattle productive lifespan could decrease the environmental footprint of milk production because fewer heifers need to be raised (De Vries \& Marcondes, 2020). Therefore, improving dairy cow welfare is of key importance to reducing the environmental impacts of dairy farming.

Consumer food preferences are evolving. The number of people adopting a vegan diet is increasing (Alcorta et al., 2021) and those that continue to consume animal products seek confirmation that food is produced in an ethical, animalfriendly manner (Cembalo et al., 2016). However, while recent work confirmed Ireland is performing well in certain areas of cow welfare, there remains considerable scope to improve (Crossley et al., 2021). Indeed, Ireland's recent Animal Welfare Strategy highlights the importance of doing so (DAFM, 2021). Demonstration of high cow welfare standards is also crucial to maintain Ireland's image as a sustainable producer of dairy products in order to maximise market returns for increased dairy production in competitive markets worldwide (DAFM, 2015). As such, dairy cow welfare must be a priority. In this regard, there is a requirement within the Irish dairy sector for schemes to monitor, benchmark and incentivise improvements to cow and young stock welfare on farms.

\section{Beef cattle welfare}

At present, there is no specific EU legislation addressing the welfare of cattle kept for beef production (European Commission, 2001). Welfare concerns with veal production led to the implementation first in 1991, and later in 2008, of legislation laying down minimum standards for their protection (Council Directive 2008/119/EC, 2008).

\section{Castration}

The castration of male calves intended for beef production is probably the most significant acute tissue- and structurealtering procedure that beef cattle commonly undergo, apart from the act of slaughter itself. Thus, castration has the capacity to represent a major source of acute stress and trauma, and also one which may reasonably be used to investigate links between acute stress and alterations in immune system function in cattle. There are also concerns regarding the ethical and social acceptability of castration procedures.

Calves are castrated because it reduces management problems associated with aggressive and sexual behaviour. However, from an animal welfare perspective, the inflammation and pain due to handling and tissue trauma are potent activators of the hypothalamic-pituitary-adrenal
(HPA) axis (Earley \& Crowe, 2002) and cause distress. The three main castration methods are: a rubber ring or latex bands to restrict the flow of blood to the scrotum, bloodless castration by crushing the spermatic cords with the Burdizzo and surgical castration. There is a general perception that delaying castration could extend the production advantages of keeping animals as bulls until weaning or beyond puberty. Keane (1999) showed no advantage in delaying castration of bulls from birth up to 17 mo of age in terms of live weight, growth rate or carcass weight at slaughter.

The issue of pain relief during castration of bulls is increasingly important in the scrutiny of the ethical treatment of farmed animals. Systemic analgesia with a non-steroidal antiinflammatory drug (NSAID), ketoprofen, was more effective than local or epidural anaesthesia in modulating cortisol and inflammatory responses, and in the suppression of immune function (Earley \& Crowe, 2002). The NSAID, ketoprofen, effectively suppressed the surgical castration-induced peak cortisol response, and the 12-h integrated cortisol response by $56 \%$ relative to surgery alone and by $40 \%$ relative to surgery with local anaesthesia in 5.5-mo-old Friesian calves. Furthermore, a combined administration of ketoprofen and local anaesthesia delayed the peak cortisol response by $4 \mathrm{~h}$ relative to surgery alone (Earley \& Crowe, 2002). Calves at $47 \mathrm{~d}$ of age have lower plasma cortisol responses to castration compared to older castrated calves (76-165 d of age), and the use of an NSAID is a better alternative to local anaesthesia for the alleviation of inflammatory and painassociated behavioural responses to castration (Ting et al., 2005). The findings showed that calves at $47 \mathrm{~d}$ of age exhibited lower stress responses (plasma cortisol and inflammatory responses) to Burdizzo castration compared with older calves (76-165 d of age). Issues of pain relief during routine husbandry procedures are likely to become increasingly important as societal scrutiny into the ethical treatment of farmed animals converges with the scientific evidence on the acute and chronic painfulness of routine husbandry practices.

\section{Weaning}

In Ireland, spring-born suckler beef calves are typically weaned at the end of the grazing season in autumn, between 6 and 9 mo of age, at which time they are also housed (Drennan \& McGee, 2009). Weaning of the beef calf under modern cattle production systems constitutes a multi-factorial stressor as it incorporates nutritional, physical and psychological elements (Hickey et al., 2003b). The weaning process involves separating the calf from its mother, resulting in numerous stressful events including dietary change, housing and social reorganisation. Indeed weaning of beef calves is one of the most stressful events in the calf's lifetime (Hickey et al., 2003b; Blanco et al., 2009; Lynch et al., 2010a, 2010b, 2011; O'Loughlin et al., 2011, 2012, 2014). 
Lynch et al. (2010a) identified that beef calves that were abruptly weaned and returned to familiar pasture had a less marked stress response than calves that were abruptly weaned and introduced to a new environment of a slatted floor shed and were offered a new diet of grass silage ab libitum plus supplementary concentrates simultaneously. The more marked stress response was attributed to decreased number of lymphocytes, the attenuated production of interferon- $\gamma$ (IFN- $\gamma$ ) and greater concentrations of the acute phase protein, fibrinogen, post-weaning in abruptly weaned and housed calves compared with those that were abruptly weaned and returned to pasture.

Additionally, Lynch et al. (2010a, 2010b) demonstrated that movement from a pasture environment to a housing environment in a slatted floor shed is capable of inducing a transient stress response in beef calves and cows. Collectively, these studies identified a profile in which neutrophilia and concurrent lymphopenia are evident for a brief period following relocation. Due to the pronounced neutrophilia and lymphopenia observed by Lynch et al. (2010a, 2010b), a more in-depth examination of the effects of abrupt weaning on neutrophil function and lymphocyte immunophenotypes was undertaken by Lynch et al. (2012). Transient neutrophilia was evident post-weaning, and this population of circulating neutrophils was less active in terms of phagocytosis than the neutrophil population in circulation prior to weaning (Lynch et al., 2012). Utilising the profile of changes observed in neutrophil number and function and lymphocyte subsets identified by Lynch et al. (2012) as sensitive biomarkers of weaning stress in beef calves, the provision of concentrate supplementation pre-weaning was examined to determine if this practice could ameliorate the stress response post-weaning. Calves that were offered concentrate supplementation pre-weaning had a lesser degree of neutrophilia compared with calves that were not supplemented pre- and post-weaning (Lynch et al., 2012). Other weaning management practices include the use of antisuckling devices (nose clips) for a period prior to weaning (Haley et al., 2005), fence-line contact between calf and dam post-weaning (Stookey et al., 1997) and a combination of both practices before complete separation (Newberry \& Swanson, 2008).

There are limited studies on the effects of weaning on beef cows. In line with the findings of Lynch et al. (2010b) and other studies examining the effects of weaning stress in beef calves (Hickey et al., 2003b; Blanco et al., 2009), weaning resulted in neutrophilia and concurrent lymphopenia which was coupled with decreased in vitro production of IFN- $\gamma$ and increased acute phase response in beef cows. Thus, it is apparent that the beef cow is stressed by separation from her calf. However, when the magnitude and duration of these perturbations in the cow are compared with those in the calf, it appears that stress response is activated to a lesser degree and for a shorter period (Lynch et al., 2010b). Early weaning is not practiced in Ireland due to favourable climatic conditions for grass growth. Beef cows express distinct distress behaviours, such as increased vocalisations and locomotor activity following abrupt separation from their calves (Price et al., 2003). Therefore, it is reasonable to assume that physiological and immunological alterations in abruptly weaned beef calves would also be seen in beef cows following abrupt separation from their offspring.

\section{Transport}

The infrastructure of the beef cattle industry is associated with a need for the transportation of cattle, by road and sea, including within the EU, and internationally. The buying and selling of cattle from one producer to another, the finishing of weanling calves at large feedlots and the endpoint of slaughter all necessitate transportation. Transportation can combine physical and psychological stressors, and weaning, method of and the handling during (un)loading, commingling of unfamiliar animals, loud noises, overcrowding, food and water deprivation, extreme temperature and the novelty of the truck or new feedlot facility can be individually stressful, let alone in combination with each other. Kenny \& Tarrant (1987) observed that confinement on a moving vehicle is the most stressful component of transportation. The transport of livestock can have major implications for their welfare, and there is strong public interest and scientific endeavour aimed at ensuring that the welfare of transported animals is optimal (Earley \& O'Riordan, 2006; Earley et al., 2010, 2011, 2012, 2013). Physical factors such as noise or vibrations, psychological/ emotional factors, such as unfamiliar environment or social regrouping, and climatic factors, such as temperature and humidity, are also involved in the transport process. Increased neutrophil and decreased lymphocyte numbers following transportation are documented (Earley \& O'Riordan, 2006; Earley et al., 2010, 2011, 2012, 2013).

Transport journeys from Ireland to France $(23 \mathrm{~h})$ and Italy were investigated both with bulls and heifers, in which the cattle remained in their vehicle transporters (Earley \& Murray, 2010; Earley et al., 2012). The percentage of time that bulls spent lying was $63.5 \%$ for the sea journey and $35.4 \%$ for the journey from the French lairage to the Italian feedlot. While transient changes in physiological, haematological and immunological variables were found in the transported and control animals relative to baseline levels, the values were within the normal physiological range for the age and weight of animals involved. Physiological measurements made after the road and sea journeys indicated that the 24-h rest in the lairage, with hay and water freely available, was adequate to maintain homeostasis. Within the conditions of the studies (Earley \& Murray, 2010; Earley et al., 2010, 2011, 2012, 2013), there was no evidence to suggest that the health, welfare or performance of animals was adversely impaired 
as a consequence of the transport journeys. Earley et al. (2011) investigated the effect of transport by sea, from Ireland to Lebanon, on performance, physiological, immunological and behavioural responses of bulls and found no evidence to suggest that their welfare was impaired by the journey. Nevertheless, under normal commercial shipping conditions, adverse weather or disease outbreaks (in humans or animals) can prolong the journey or delay the unloading process and thereby pose potential threats to animal welfare. Hence, animal transportation is a very relevant issue for animal welfare and therefore is subject to specific legal requirements such as European Convention for the protection of animals during international transport (1968) and European Council regulation 1/2005 (EU, 2005) on the protection of animals during transport and related operations. Teagasc research on animal transport has informed the latter regulation.

\section{Housing}

The main critical issues for beef cattle welfare during housing were identified by EFSA (2006a, 2006b, 2012), the European Commission (2001) and the EU Welfare Quality ${ }^{\circledR}$ project (2009); these include: housing conditions, areas for feeding, walking and resting, space allowance and flooring, social and maternal behaviour, dominance, grouping and regrouping of animals. Most recently, concern for the welfare of finishing cattle, particularly in relation to housing conditions (space allocation and floor type), was expressed at national, EU and OIE levels. There is the view that conventional slatted floors without access to lying areas should be replaced by more animal-friendly systems. Outdoor wintering of beef animals is not an option on many Irish farms due to poaching of ground conditions. Winter housing is therefore a necessary alternative and is dominated by concrete slatted floored sheds. The main floor types used for accommodating beef cattle in Ireland are concrete slatted floors (CSFs), CSF overlaid with rubber mat (RM) and loose bedded systems, mainly containing straw (Mazurek et al., 2010). Many farms have a combination of both these floor types.

As well as facilitating winter feeding and management, accommodating cattle indoors provides additional benefits such as preventing land poaching and protecting animals from inclement weather conditions. Since the 1960s, the number of beef cattle on CSF increased (Wechsler, 2005). Although they cost more to construct initially, CSFs are popular due to the lower labour input required for the removal of slurry than would be required with solid floor systems (Lowe et al., 2001a).

The duration of the indoor housing period varies from 3 to 6 mo depending on climate, soil type and management system. In some systems, particularly with spring-born beef bulls, the housing period is not limited to the winter months as bulls may be housed after their first summer and finished intensively indoors over a period of 9 or 10 mo (Keane \& Allen, 1998;
Keane, 2003; Drennan \& McGee, 2009). While steers tend to have shorter housing periods than bulls, the amount of time they spend indoors is greater as they are usually slaughtered at 24 mo or above (Keane \& Allen, 1998; Keane, 2003; Keane, 2010), thus spending two winter periods housed indoors.

There are suggestions to increase the space allowances per animal on CSF to $3.0 \mathrm{~m}^{2}$ for a $500-\mathrm{kg}$ animal $\pm 0.5 \mathrm{~m}^{2}$ per $100 \mathrm{~kg}$ above or below this (Scientific Committee on Animal Health and Animal Welfare [SCAHAW], 2001). The majority of studies carried out on the effect of space allowance on the performance and welfare of finishing beef cattle on CSF investigated space allowances below $3.0 \mathrm{~m}^{2}$. Fisher et al. (1997a, 1997b) reported that housing finishing heifers, weighing $560 \mathrm{~kg}$, at space allowances below $2.0 \mathrm{~m}^{2}$, instead of at 2.5 and $3.0 \mathrm{~m}^{2}$ per animal, impaired performance and lying time. Furthermore, Hickey et al. (2003a) reported a reduction in carcass weight and a decrease in the production of IFN$\gamma$ to the mitogen Concanavalin-A, a marker of cell-mediated immunity, in steers, weighing $610 \mathrm{~kg}$, housed at $1.5 \mathrm{~m}^{2}$ per head compared to $3.0 \mathrm{~m}^{2}$. Similarly, Gupta et al. (2007) found that housing bulls at $1.2 \mathrm{~m}^{2}$ compared to $2.7 \mathrm{~m}^{2}$ reduced performance and raised plasma cortisol concentrations suggesting that the performance and stress response of animals at the lower space allowance was inhibited. Keane et al. (2017) investigated the effect of space allowance and floor type on performance and welfare of finishing beef heifers at either (i) $3.0 \mathrm{~m}^{2}$, (ii) $4.5 \mathrm{~m}^{2}$ or (iii) $6.0 \mathrm{~m}^{2}$ space allowance per animal on a CSF and (iv) $6.0 \mathrm{~m}^{2}$ space allowance per animal on a straw-bedded floor, for $105 \mathrm{~d}$. The number of heifers lying at any one time was greater on straw than on CSF. Space allowance and floor type had no effect on the number of hoof lesions gained or on any of the haematological or metabolic variables measured. Hence, increasing space allowance has no negative impact on performance but did improve cleanliness.

The increased popularity of CSF led to an increased interest in floor types that combine the labour-saving efficiency of CSF with a softer floor surface (Benz et al., 2002). Rubber mats were developed for this purpose, as they can be overlaid on CSF with relative ease. There are numerous different types of RMs available. The structure of individual varieties can vary greatly in terms of hardness, friction, compression and abrasiveness; therefore, their effects on animal performance and welfare vary greatly between studies. Lowe et al. (2001a) compared CSF with CSF overlaid with RM and found no difference in average daily gain (ADG) or carcass weight of cattle. In contrast, Keane et al. (2015) reported a greater ADG for cattle on CSF overlaid with the Durapak RM than on CSF, but found no difference in carcass weight.

Wechsler (2011) recommended that CSF should not be used for housing beef cattle and instead must be replaced with alternative floor types such as RM or straw. Previous research 
showed that cattle on RM can develop more leg swellings (Graunke et al., 2011) and hoof lesions (Earley et al., 2015, 2017; Keane et al., 2015) compared to those on CSF. Others have concluded that the RM may not be the ideal replacement for CSFs however, as they do not provide sufficient claw wear thereby causing overgrown claws (Bergsten, 2010). This can lead to further problems such as heel erosion caused by a displacement of the main load-bearing points (Dembele et al., 2006). The results of Keane et al. (2015) indicate that housing bulls on an RM improved daily live weight; however, this result was not reflected in slaughter or carcass weight. While there was no evidence of lameness in bulls on RM in that study, the increased number of hoof lesions suggests that hoof health may be compromised. In a recent study, Earley et al. (2017) reported similar findings in finishing beef steers using three different RMs. Prior to the adoption of concrete slatted housing, the most common floor type for cattle housed indoors was straw bedding (Maton et al., 2012). From an animal welfare perspective, straw bedding is preferable (Burgess \& Hutchinson, 2005) as cattle display a strong preference for straw bedding and would rarely choose to lie on a slatted floor if there was any other floor type available (Lowe et al., 2001b). However, straw bedding has its limitations in relation to labour efficiency, space requirements, straw availability and cost (Tuyttens, 2005). For example, in Ireland, if all beef producers replaced CSF with straw-bedded systems, the national supply of straw would run out within 1 mo (Wilkinson, 1998).

Additional topics at present that feature most prominently are (i) antimicrobial use and resistance, and (ii) calf health, with particular reference to factors affecting morbidity and early mortality. The two topics are interdependent and are addressed in more detail in Mee et al. (2022).

\section{Pig welfare}

Pigs are protected by a specific EU directive (Council Directive 2008/120/EC) which lays down minimum standards for their protection (e.g. standards relating to flooring, living space, access to materials for rooting). Most Irish pigs are managed in high-density, low-complexity environments, which are sub-optimal with regard to the animals' biological needs. Unfortunately, the consequence is a high prevalence of health and welfare problems for pigs across all production stages (piglets: Quinn et al., 2015; sows: Boyle et al., 1998, 1999; Quinn, 2014; weaner, grower and finisher pigs: Quinn, 2014; van Staaveren et al., 2017, 2018; da Costa et al., 2020).

\section{Sows and gilts}

Tethering of pregnant sows (permanently tied by a collar around the neck or chest for the duration of pregnancy) was common in the EU for several decades, until it was banned from 2006 under the 1991 Pigs Directive. In the lead up, a longitudinal assessment of skin lesions in stall-housed sows throughout the production cycle and a cross-sectional study of the same lesions in tethered and stall-housed pregnant sows were conducted on 25 commercial pig farms (Boyle et al., 1999). In general, there was a high prevalence of lesions to the hind limbs, reflecting the difficulty for sows of manoeuvring in close confinement and the unforgiving nature of the flooring used. Boyle et al. (1998) also determined that high culling rates in the early parities for reproductive failure, locomotor problems, disease and injury reflected major challenges to gilts' ability to adapt to close confinement on entering the breeding herd.

Given these issues it was not surprising that in 2008 the EU imposed a partial ban on sow stalls (Council Directive 2008/120/EC), which came into force on 1 January 2013. This required sows to be group housed from 4 wk after service. However, aggression between sows at mixing, during competition for access to resources and due to hunger, is a major cause of stress and injury, and can have a negative impact on sow reproductive performance (Read et al., 2020; Lagoda et al., 2021). Research on group housing was already underway in Ireland prior to the EU ban (e.g. Boyle et al., 2002a; O'Connell et al., 2003, 2004; O'Connell, 2007) prompted by the demand from the UK which banned gestation stalls in 1998. Subsequent investigation of high-fibre diets and foraging substrates, both requirements of EU legislation (Stewart et al., 2008, 2010, 2011), aided identification of strategies to improve welfare. Research comparing group and stall housing systems for pregnant sows confirmed the major problem of lameness in the former (Calderon Diaz et al., 2014), and epidemiological research on lameness in all classes of pigs confirmed that the ubiquity of fully slatted concrete flooring on Irish pig farms was a major contributory factor (Quinn, 2014). On-farm research then found that rubber flooring had considerable benefits to sow welfare, locomotory ability, reproductive performance, etc. during pregnancy (Calderon Diaz et al., 2013, 2014; Calderón-Díaz \& Boyle, 2014a, 2014b; Lagoda et al., 2021) although these did not carry over to during the farrowing/lactation period (Calderon Diaz \& Boyle, 2014a).

On most Irish farms, gilts destined to enter the breeding herd are treated in the same way as finisher pigs, and fed diets designed for fast growth rates and lean meat deposition. However, Quinn (2014) confirmed hypothesised benefits of preferentially treating young replacement gilts in terms of diet and housing on farm. Furthermore, terminal line gilts fed a restricted diet formulated for fat rather than lean deposition and supplemented with minerals for optimal bone and joint development had improved locomotion scores likely associated with slower weight gain (Quinn et al., 2015). More 
recent work by Hartnett et al. (2019, 2020a) confirmed that integrating supplementary minerals into maternal line gilt diets improved joint health (i.e. less cartilage damage), reduced claw lesion severity and improved production performance throughout life (Hartnett et al., 2020b).

Hartnett et al. (2020a) showed that keeping replacement gilts in all-female groups from weaning was likely responsible for the benefits described above, as gilts were exposed to less sexual and aggressive behaviour performed by the males. Ireland is one of few European countries that raises male pigs as entire boars. This offers welfare advantages to piglets as they are spared surgical castration in the first week of life (Llamas Moya et al., 2006a, 2006b, 2008b, 2008c). However, pigs in entire male pig production systems suffer challenges to welfare later in life arising from intense aggressive and sexual behaviour during the finisher (Bjorklund \& Boyle, 2006; Teixeira \& Boyle, 2014) and pre-slaughter (van Staaveren et al., 2015) stages.

\section{Farrowing facilities}

Sows are usually confined in crates for the farrowing and lactation period to protect piglets from crushing, and enable quick, safe and easy checking of the animals by the stockperson. Protection from crushing is ever-more important with the increases in litter size that occurred due to selection for higher sow productivity (Boyle et al., 2021). Larger litters are also associated with increased competition between piglets for access to a teat and considerable fighting between piglets when trying to establish the "teat order" (Fraser \& Thompson, 1991). Associated injuries to the sows' teats and piglets' faces are reduced by clipping the needle teeth; pilot work at Teagasc demonstrated that leaving these teeth intact results in facial lesions and reduced growth rate for piglets during the first three critical days of life (O'Driscoll \& Schmitt, 2016). However, even when carried out for welfare reasons, teeth clipping can still cause immediate and long-term pain (Sinclair et al., 2018), and as such is regulated under Council Directive 2008/120/ EC. An alternative is grinding, which has benefits for sows and piglets (Lewis et al., 2005a, 2005b, 2005c; Llamas Moya et al., 2006a, 2006b). Providing piglets with shredded paper and ropes in the farrowing crate redirects their behaviour away from the sow and may also help to reduce lesions (Lewis et al., 2006).

Even older research on farrowing facilities extends back to the mid-1990s when the injurious nature of floor types used in farrowing crates for piglet skin and feet as well as negative impacts on piglet behaviour were documented (Leonard et al., 1996a, 1996b; O'Connell et al., 1996). Early research also documented the injurious nature of confinement in farrowing crates for sows (Boyle et al., 1999, 2000a, 2002a, 2002b). One of the first attempts to reduce injury and improve sow comfort was through the use of RMs in the farrowing crate (Boyle et al., 2000b).

The introduction of group housing during gestation posed yet another new challenge for gilts and sows; freedom during pregnancy (or most of their life to that point), followed by sudden confinement prior to farrowing, can act as a stressor (Boyle et al., 2000a, 2002a; Baxter et al., 2011). However, a strategy whereby sows are confined only from the initiation of milk let-down until $4 \mathrm{~d}$ post-farrowing (i.e. free lactation) could somewhat address this issue. Indeed sows in free lactation pens have improved locomotory ability at weaning relative to sows in crates, use all orientations in the pen and have less tear staining under the left eye (indicative of mental stress; DeBoer et al., 2015) at weaning (Kinane, 2020). Most importantly, mortality was not higher than in standard crates; there was slightly more crushing in the free lactation pens after the crates were opened, but this was offset by fewer deaths from hunger and failure to thrive (Kinane et al., 2021). Piglets from the free lactation pens also tended to perform less damaging behaviour, weighed more at weaning, were significantly heavier at slaughter and took fewer days to reach the target weight of $105 \mathrm{~kg}$.

\section{Tail biting}

Irish producers recognise tail biting (a behavioural disorder which occurs when pigs experience a level of stress which is beyond their coping abilities) as a serious issue (Haigh \& O'Driscoll, 2019), although over 99\% of Irish pigs' tails are docked to prevent biting, and about two-thirds of tails exhibit some evidence of damage (Harley et al., 2012, 2014). Inability to perform natural behaviours and inadequate housing and management are the primary triggers (D'Eath et al., 2014; Valros, 2018). Improving compliance with the ban on routine tail docking is currently one of the European Commission's priorities in the area of animal welfare (Nalon \& De Briyne, 2019). However, a significant challenge in Ireland is the physical structure of most pig facilities (e.g. fully slatted systems) which means that the recommended gold standard enrichment material, straw bedding on the floor of the pen (D'Eath et al., 2014), cannot be provided.

Initial Irish research focused on a dietary solution. However, neither $\mathrm{Mg}$ supplementation nor a higher fibre level in the diet (both of which were hypothesised to have a calming effect) reduced biting or damage to tails (O'Driscoll et al., 2013a, 2013b; Chou et al., 2020a). Work conducted on commercial farms attempted to identify enrichment materials which could be attached to the walls; soft wood, such as spruce, was identified as being more favourable to pigs than harder wood (beech, larch and Scots pine; Chou et al., 2018), or than compressed straw blocks (Haigh et al., 2019). Indeed, soft wood and rubber are used more often by pigs than harder items (Chou et al., 2020b). However, these materials were 
insufficient alone to prevent biting outbreaks in undocked pigs (Chou et al., 2020a). As such, Teagasc research moved on to investigating greater enrichment allowances, including racks of loose material (Chou et al., 2019, 2020c; D'Alessio et al., 2021; Misra et al., 2021); grass was favoured by pigs over straw, paper and miscanthus (Chou et al., 2019). Future work will aim to identify materials which are easily available, affordable, have a low biosecurity risk and can be stored without risk of degradation.

\section{Link between pig welfare and pig health}

On-farm research by Teagasc documented poor welfare arising from sub-optimal management and housing practices (Diana et al., 2019a; da Costa et al., 2021) and associated deficiencies in performance and health and increased mortality (Calderon Diaz et al., 2017a, 2017b, 2018). Antibiotics are viewed by farmers as the most cost-effective way to address health and performance challenges, and thereby protect pig welfare (Diana et al., 2021), but from January 2022 any prophylactic use is banned. However, Teagasc research found that by removing in-feed medication in current systems, and by employing good management and housing practices, there are no adverse effects on pig health, welfare or productivity (Diana et al., 2017, 2019b).

\section{Poultry welfare}

Most European citizens consider it is important to protect the welfare of farm animals (European Commission, 2016d), and there appears to be particular concern about the welfare of poultry (Clark et al., 2016). The use of cages for laying hens is particularly contentious. While conventional or "battery" cages were prohibited under EU legislation from 2012, there is now increased momentum to move to cagefree systems entirely. This would invariably provide birds with more behavioural freedom, but is associated with increased mortality (Weeks et al., 2016). In free-range systems, this mortality may result from a variety of causes including disease, smothering and predation (Elson, 2015; Rayner et al., 2016; Bestman \& Bikker-Ouwejan, 2020). Some of the welfare issues associated with cage-free production contributed to increased interest in the use of more "robust" breeds of hens that are better able to cope with these environments (e.g. Fernyhough et al., 2019).

Concern over the use of cages means much of the public conversation about poultry welfare focused on the laying hen sector in recent years. This section will therefore focus on the broiler chicken sector, the scale and importance of which was outlined in the Introduction. There are different aspects of broiler production that could be discussed, including welfare during handling, transport and slaughter, and specifically of broiler breeders. Our focus, however, will be on environmental enrichment strategies for broiler chickens in order to reflect a key research theme on the island of Ireland. The majority of broiler chickens are reared indoors over a 5-6-wk period in groups of more than 20,000 birds. The fact that they can reach slaughter weight in such a short time reflects, to a large extent, targeted genetic selection for production traits such as growth rate. This rapid growth is associated with health and welfare problems, including leg health issues and cardiovascular disease (see EFSA, 2010; Hartcher \& Lum, 2019), and genetic selection strategies are associated with reduced activity levels (McLean et al., 2002). Levels of activity often decline with age (Weeks et al., 2000), and this inactivity can further add to health problems. While there is much focus on bird genetics, low levels of behavioural activity may also reflect lack of appropriate stimulation within housed systems. This is supported by the fact that increased activity is shown by fast-growing broilers in response to certain environmental enrichment (Riber et al., 2018).

In order to address welfare concerns while also meeting global demand for chicken meat, there is increased interest in developing enhanced housing systems and using slowergrowing breeds. This is evident in the commitments being made by many leading companies in the food supply chain (European Chicken Commitment, 2018). It is also evident in the enhanced housing systems already emerging from within the industry. Research into the use of slower-growing breed types gathered pace in recent years, and studies show benefits including improved health and reduced mortality (Rayner et al., 2020) and improved gait (Dixon, 2020). Continued evaluation of the welfare outcomes of different slower-growing breed types reared under commercial conditions would be beneficial. Enhanced housing systems typically involve provision of environmental enrichment items, natural light and additional space. These systems emerged as part of voluntary initiatives or quality assurance schemes, and there is significant progress in recent years in capturing actual welfare outcomes of these strategies on commercial farms. This is essential to ensuring that these policies have a tangible effect on broiler welfare, and progress in relation to this area will be discussed in more detail below.

\section{Environmental enrichment items}

Environmental enrichment items in commercial broiler houses provide birds with an opportunity to engage in highly motivated behaviours, and may also stimulate general activity levels and consequently improve leg health. While there is a wealth of research into appropriate environmental enrichment for pigs, the same does not appear to apply with broiler chickens. This is perhaps reflected in the fact that provision of enrichment items to broiler chickens is not required under EU legislation. As mentioned, however, these items are often required as part 
of quality assurance schemes or by others in the sector such as retailers. While this is a very positive step, it is important to ensure that what is provided meets the needs of the birds. The enrichment items typically provided on commercial farms include straw bales, pecking objects and perches, and research shows that these items are used by broilers. For example, research conducted in Northern Ireland by Baxter et al. (2018b) showed that an average of 30 birds clustered around straw bales on commercial farms, suggesting that they provide perceived protection. The birds also dismantle the bales over time on commercial farms, which helps to maintain litter quality, and also sometimes use them as perches. Research by this group also showed that pecking objects such as string and chains are used quite frequently by broiler chickens (Bailie \& O'Connell, 2015; Baxter \& O'Connell, 2019). For this type of enrichment item, more research is needed on optimum level of provision. Providing pecking objects such as string at minimum levels stipulated in some high welfare quality assurance schemes (e.g. 1 per 1,000 birds) does not appear to lead to sustained beneficial effects on general activity levels or leg health in commercial broilers (Bailie \& O'Connell, 2015; Bailie et al., 2018b). Similarly, research in commercial windowed houses showed limited benefits of providing 1.3 straw bales per 1,000 birds on general activity levels and leg health (Bailie et al., 2013), and no additional benefits of increasing levels to 2 bales per 1,000 birds (Bailie \& O'Connell, 2014).

Perching is a highly motivated behaviour in chickens, but the type of perch provided on commercial farms is likely to have a significant impact on beneficial effects. Bailie \& O'Connell (2015) did not find any significant benefits of providing standard bar perches in commercial broiler houses on activity levels and leg health. Subsequent research by Bailie et al. (2018a) demonstrated a preference among fast-growing birds for platform rather than bar perches, which corresponds with findings by Norring et al. (2016). This preference may be linked to the conformation of the bird, and further research will be needed to determine optimum perch type for slowergrowing breed types. As with other types of enrichment items, more evidence is needed on optimum level of provision of perches. Recently, Baxter et al. (2020) investigated four different levels of platform perch provision $(0,0.5,0.6$ and $0.7 \mathrm{~m}^{2} / 1,000$ birds) in commercial houses. They found evidence of reduced fearfulness among birds when platform perches were provided, and high levels of perch occupancy in all treatments (on average $11.5 \mathrm{birds} / \mathrm{m}^{2}$ ), but no significant differences between treatments in terms of average gait score or activity level.

It may also be important to design environmental enrichment strategies that facilitate other important behaviours in broiler chickens. These birds are motivated to perform dustbathing but litter in commercial houses may not always be suitable for this type of behaviour. Research by Baxter et al. (2018a) investigated the preferences of broiler chickens for different dustbathing material (including peat, oat hulls, straw pellets, clean wood shavings and standard litter), and found more dustbathing behaviour in peat and oat hulls than in the other materials provided. Follow-on research investigated the effect of providing discrete dustbaths filled with oat hulls in commercial broiler houses and showed that they promoted more foraging behaviour than straw bales (Baxter et al., $2018 b)$. Importantly, the provision of dustbaths also led to a significant improvement in gait score at the end of the production cycle. This whole-house effect on this leg health measure demonstrates the potential benefits achievable with appropriate environmental enrichment. The engagement that the broilers showed with dustbaths led to further research to investigate if use of other types of enrichment such as pecking objects may be increased by placing them within "activity clusters" containing both dustbaths and straw bales (Baxter \& O'Connell, 2019). There were no obvious beneficial effects on use of the enrichment items when they were clustered together rather than distributed separately throughout the house; however, further research on optimum placement of enrichment items within the house would be beneficial. This will be aided by developments in tracking technology (e.g. Baxter \& O'Connell, 2020) which will enable long-term monitoring of the use of different parts of the house by broiler chickens.

\section{Light and space}

Under current EU legislation, broilers must be provided with at least $6 \mathrm{~h}$ of darkness in each 24-h period during much of the production cycle. Research by Schwean-Lardner et al. (2012, 2013) indicated that longer dark periods were beneficial for bird welfare. This might be particularly important at the start and the end of the production cycle when longer light periods are permitted. The quality of light provided also appears to have a significant impact on broiler welfare. Bailie et al. (2013) investigated the effects of providing commercially housed broilers in Northern Ireland with access to natural light through windows and found significant benefits in terms of activity levels and leg health. This and more recent research by De Jong \& Gunnink (2019) appear to validate a requirement to provide natural light within enhanced housing. These effects may reflect the increased intensity of light and also the presence of ultraviolet (UV) wavelengths in windowed housing (Bailie et al., 2013). Research evidence from commercial systems also supports the provision of additional space. In a study involving almost 2 million birds, Bailie et al. (2018b) showed increased severity of dermatitis lesions when stocking density increased from 30 to 34 or 36 $\mathrm{kg} / \mathrm{m}^{2}$. Dawkins et al. (2004) also showed evidence of poorer gait at higher stocking densities in a large on-farm trial that 
evaluated space allowances of $30,34,38,42$ and $46 \mathrm{~kg} / \mathrm{m}^{2}$. Importantly, however, they also indicate that conditions on the farm (likely linked to litter and air quality) had a more important impact on broiler welfare than the space allowance provided.

\section{Conclusions}

The science of animal welfare has evolved considerably over the last $60 \mathrm{yr}$ and with it the recognition that animals are sentient beings. This is partly due to changing attitudes towards animals and also to the increased intensification of animal production in western countries. Although this intensification greatly increased efficiency and levels of production from animal agriculture, it also brought new problems to be addressed by animal and veterinary scientists, as well as a questioning of many farming practices by the consuming public. The OECD (2020) acknowledged that animal welfare is an emerging trade issue, and the international conventions already in place and ongoing work with the OIE confirms this. Throughout this review, emphasis was placed on the scientific evidence informing three main aspects of livestock animal welfare: (i) physical health and well-being; (ii) naturalness, meaning that animals can express normal behaviour; and (iii) subjective states, in that animals experience positive states and that negative states (e.g. pain) are minimised.

\section{Acknowledgements}

The authors acknowledge the research funding they have received over the years and the invitation to write this paper from the Irish Journal of Agriculture and Food Research. The broiler chicken element of the paper includes material summarised from a chapter prepared by N. O'Connell for a publication funded by Eurogroup for Animals (Eurogroup for Animals, 2020).

\section{References}

Alcorta, A., Porta, A., Tárrega, A., Alvare, M.D. and Vaquero, M.P. 2021. Foods for plant-based diets: challenges and innovations. Foods 10: 293.

Arnott, G., Ferris, C.P. and O'Connell, N.E. 2017. Review: Welfare of dairy cows in continuously housed and pasture-based production systems. Animal 11: 261-273.

Bailie, C.L. and O'Connell, N.E. 2014. The effect of level of straw bale provision on the behaviour and leg health of commercial broiler chickens. Animal 8: 1715-1721.
Bailie, C.L. and O'Connell, N.E. 2015. The influence of providing perches and string on activity levels, fearfulness and leg health in commercial broiler chickens. Animal 9: 660-668.

Bailie, C.L., Ball, M.E.E. and O'Connell, N.E. 2013. Influence of the provision of natural light and straw bales on activity levels and leg health in commercial broiler chickens. Animal 7: 618-626.

Bailie, C.L., Baxter, M. and O'Connell, N.E. 2018a. Exploring perch provision options for commercial broiler chickens. Applied Animal Behaviour Science 200: 114-122.

Bailie, C.L., ljichi, C. and O'Connell, N.E. 2018b. Effects of stocking density and string provision on welfare-related measures in commercial broiler chickens in windowed houses. Poultry Science 97: 1503-1510.

Balzani, A., Aparacida Vaz do Amaral, C. and Hanlon, A. 2021. Perspective on the use of sexed semen to reduce the number of surplus male dairy calves in Ireland: a pilot study. Frontiers in Veterinary Research 7: 1243.

Barkema, H.W., von Keyserlingk, M.A.G., Kastelic, J.P., Lam, T.J.G.M., Luby, C., Roy, J.P., LeBlanc, S.J., Keefe, G.P. and Kelton, D.F. 2015. Invited review: Changes in the dairy industry affecting dairy cattle health and welfare. Journal of Dairy Science 98: 7426-7445.

Barry, J., Kennedy, E., Sayers, R., de Boer, I.J.M. and Bokkers, E.A.M. 2019. Development of a welfare assessment protocol for dairy calves from birth through to weaning. Animal Welfare 28: 331-344.

Barry, J., Bokkers, E.A.M., de Boer, I.J.M. and Kennedy, E. 2020. Preweaning management of calves on commercial dairy farms and its influence on calf welfare and mortality. Animal 14: 2580-2587.

Baxter, M. and O'Connell, N.E. 2019. Does grouping environmental enrichments together affect the way they are used by commercially housed broiler chickens? Applied Animal Behaviour Science 210: 52-59.

Baxter, M. and O'Connell, N.E. 2020. Testing ultra-wideband technology as a method of tracking fast-growing broilers under commercial conditions. Applied Animal Behaviour Science 233: 105150.

Baxter, E.M., Lawrence, A.B. and Edwards, S.A. 2011. Alternative farrowing systems: design criteria for farrowing systems based on the biological needs of sows and piglets. Animal 5: 580-600.

Baxter, M., Bailie, C.L. and O'Connell, N.E. 2018a. An evaluation of potential dustbathing substrates for commercial broiler chickens. Animal 12: 1933-1941.

Baxter, M., Bailie, C.L. and O'Connell, N.E. 2018b. Evaluation of a dustbathing substrate and straw bales as environmental enrichments in commercial broiler housing. Applied Animal Behaviour Science 200: 78-85.

Baxter, M., Richmond, A., Lavery, U. and O'Connell, N.E. 2020. Investigating optimum level of platform perch provision for windowed broiler housing. Applied Animal Behaviour Science 225: 104967.

Beausoleil, N.J. and Mellor, D.J. 2015. Advantages and limitations of the 'Five Domains' model for assessing animal welfare impacts 
associated with vertebrate pest control. New Zealand Veterinary Journal 63: 37-43.

Beaver, A., Meagher, R.K., Weary, D.M. and von Keyserlingk, M.A.G. 2019. Invited review: A systematic review of the effects of early separation on dairy cow and calf health. Journal of Dairy Science 102: $5784-5810$.

Benz, B., Wandel, H. and Jungbluth, T. 2002. Yielding walking areas in loose housing systems. Proceedings of the 12th International Symposium on Lameness in Ruminants (ed. J.K. Shearer), Orlando, Florida, pages 280-283.

Bergsten, C. 2010. Impact of flooring on claw health and lameness. Advances in Dairy Technology: Proceedings of the Western Canadian Dairy Seminar 22: 241-251.

Bestman, M. and Bikker-Ouwejan, J. 2020. Predation in organic and free-range egg production. Animals 10: 177.

Bjorklund, L. and Boyle, L.A. 2006. Effects of finishing boars in mixed and single sex groups and split marketing on pig welfare. Acta Veterinaria Scandinavica 48: 2.

Blanco, M., Casasús, I. and Palacio, J. 2009. Effect of age at weaning on the physiological stress response and temperament of two beef cattle breeds. Animal 3: 108-117.

Blokhuis, H.J., Veissier, I., Miele, M. and Jones, B. 2010. The Welfare Quality ${ }^{\circledR}$ project and beyond: safeguarding farm animal wellbeing. Acta Agriculturae Scandinavica 60: 129-140.

Botreau, R., Veissier, I., Butterworth, A., Bracke, M. and Keeling, L. 2007. Definition of criteria for overall assessment of animal welfare. Animal Welfare 16: 225-228.

Botreau, R., Veissier, I. and Perny, P. 2009. Overall assessment of animal welfare: strategy adopted in welfare quality. Animal Welfare 18: 363-370.

Boyle, L.A. and Mee, J.F. 2021. Factors affecting the welfare of unweaned dairy calves destined for early slaughter and abattoir animal-based indicators reflecting their welfare on-farm. Frontiers in Veterinary Science 8: 645537.

Boyle, L.A., Leonard, F.C., Lynch, P.B. and Brophy, P. 1998. Sow culling patterns and sow welfare. Irish Veterinary Journal 51: 354-357.

Boyle, L.A., Leonard, F.C., Lynch, P.B. and Brophy, P. 1999. Prevalence and severity of skin lesions in sows housed individually during the production cycle. Irish Veterinary Journal 52: 593-597.

Boyle, L.A., Leonard, F.C., Lynch, P.B. and Brophy, P. 2000a. Influence of housing system during gestation on the behaviour and welfare of gilts in farrowing crates. Animal Science 71: 561-570.

Boyle, L.A., Regan, D., Leonard, F.C., Lynch, P.B. and Brophy, P. $2000 \mathrm{~b}$. The effect of mats on the welfare of sows and piglets in the farrowing house. Animal Welfare 9: 39-48.

Boyle, L.A., Leonard, F.C., Lynch, P.B. and Brophy, P. 2002a. The influence of housing system on skin lesion scores, behaviour and responses to an ACTH challenge in pregnant gilts. Irish Journal of Agriculture and Food Research 41: 181-200.

Boyle, L.A., Leonard, F.C., Lynch, P.B. and Brophy, P. 2002b. Effect of gestation housing on behaviour and skin lesion scores of sows in farrowing crates. Applied Animal Behaviour Science 76: 119-134.
Boyle, L.A., Mee, J.F. and Kiernan, P.J. 2007. The effect of rubber versus concrete passageways in cubicle housing on claw health and reproduction of pluriparous dairy cows. Applied Animal Behaviour Science 106: 1-12.

Boyle, L., Boyle, R. and French, P. 2008. Welfare and performance of yearling dairy heifers out-wintered on a wood-chip pad or housed indoors on two levels of nutrition. Animal 2: 769-778.

Boyle, L.A., Marchewka, J., Rieple, A., Snijders, S., Berry, D.P. and Mee, J.F. 2015. ProWelCow: implications of herd expansion for dairy cow welfare. Veterinary Ireland Journal 5: 425-428.

Boyle, L.A., Carroll, C., Clarke, L., Manzanilla, E.G., Gardiner, G., McCutcheon, G., McCrum, E., McKeon, M., Lawlor, P., Lynch, B., O'Doherty, J., O'Driscoll, K. 2021. An overview of Irish pig production, research and knowledge transfer since 1960. Irish Journal of Agricultural and Food Research

Brambell, F.W.R. 1965. Report of the technical committee to enquire into the welfare of animals kept under intensive livestock husbandry systems. Command 2836, Her Majesty's Stationery Office, London, UK.

Breuer, K., Hemsworth, P.H., Barnett, J.L., Matthews, L.R. and Coleman, G.J. 2000. Behavioural response to humans and the productivity of commercial dairy cows. Applied Animal Behaviour Science 66: 273-288.

Burgess, D. and Hutchinson, W.G. 2005. Do people value the welfare of farm animals? EuroChoices 4: 36-43.

Calderón-Díaz, J.A. and Boyle, L.A. 2014a. Effect of rubber slat mats on the behaviour and welfare of group housed pregnant sows. Applied Animal Behaviour Science 151: 13-23.

Calderón-Díaz, J.A. and Boyle, L.A. 2014b. Effect of housing on rubber slat mats during pregnancy on the behaviour and welfare of sows in farrowing crates. Irish Journal of Agricultural and Food Research 53: 189-197.

Calderón-Díaz, J.A., Fahey, A.G., KilBride, A.L., Green, L.E. and Boyle, L.A. 2013. Longitudinal study of the effect of rubber slat mats on locomotory ability, body, limb and claw lesions and dirtiness of loose housed sows. Journal of Animal Science 19: $1-15$.

Calderón-Díaz, J.A., Fahey, A.G. and Boyle, L.A. 2014. Effects of gestation housing system and floor type during lactation on locomotory ability, body, limb and claw lesions, and lying-down behaviour of lactating sows. Journal of Animal Science 92: 16751685.

Calderón Díaz, J.A., Diana, A., Boyle, L.A., Leonard, F.C., McElroy, M., McGettrick, S., Moriarty, J. and Manzanilla, E.G. 2017a. Early life indicators predict mortality, illness, reduced welfare and carcass characteristics in finisher pigs. Preventive Veterinary Medicine 146: 94-102.

Calderón Díaz, J.A., Diana, A., Boyle, L.A., Leonard, F.C., McElroy, M., McGettrick, S., Moriarty, J. and Manzanilla, E.G. 2017b. Delaying pigs from the normal production flow is associated with health problems and poorer performance. Porcine Health Management 3: 13. 
Calderón Díaz, J.A., Manzanilla, E.G., Diana, A. and Boyle, L. 2018. Cross-fostering implications for pig mortality, welfare and performance. Frontiers in Veterinary Science 5: 123.

Cembalo, L., Caracciolo, F., Lombardi, A., Del Giudice, T., Grunert, K. and Cicia, G. 2016. Determinants of individual attitudes toward animal welfare-friendly food products. Journal of Agricultural and Environmental Ethics 29: 237-254.

Chou, J.-Y., D'Eath, R.B., Sandercock, D.A., Waran, N., Haigh, A. and O'Driscoll, K. 2018. Use of different wood types as environmental enrichment to manage tail biting in docked pigs in a commercial fully-slatted system. Livestock Science 213: 19-27.

Chou, J.-Y., Drique, C.M.V., Sandercock, D.A., D'Eath, R.B. and O'Driscoll, K. 2019. Rearing undocked pigs on fully slatted floors using multiple types and variations of enrichment. Animals 9: 139-155.

Chou, J.-Y., O'Driscoll, K., Sandercock, D.A. and D'Eath, R.B. 2020a. Can increased dietary fibre level and a single enrichment device reduce the risk of tail biting in undocked growing-finishing pigs in fully slatted systems? PLoS One 15: e0241619.

Chou, J.-Y., D'Eath, R.B., Sandercock, D.A. and O'Driscoll, K. 2020 b. Enrichment use in finishing pigs and its relationship with damaging behaviours: comparing three wood species and a rubber floor toy. Applied Animal Behaviour Science 224: 104944.

Chou, J.-Y., Sandercock, D.A., D'Eath, R.B. and O'Driscoll, K. 2020c. A high enrichment replenishment rate reduces damaging behaviour and increases growth rate in undocked pigs kept in fully slatted pens. Frontiers in Veterinary Science 7: 806.

Chrousos, G. 2009. Stress and disorders of the stress system. Nature Reviews Endocrinology 5: 374-381.

Clark, B., Stewart, G.B., Panzone, L.A., Kyriazakis, I. and Frewer, L.J. 2016. A systematic review of public attitudes, perceptions and behaviours towards production diseases associated with farm animal welfare. Journal of Agricultural and Environmental Ethics 29: 455-478.

Coffey, E.L., Horan, B., Evans, R.D. and Berry, D.P. 2016. Milk production and fertility performance of Holstein, Friesian, and Jersey purebred cows and their respective crosses in seasonalcalving commercial farms. Journal of Dairy Science 99: 5681-5689.

Conneely, M., Berry, D., Sayers, R., Murphy, J., Lorenz, I., Doherty, M. and Kennedy, E. 2013. Factors associated with the concentration of immunoglobulin $\mathrm{G}$ in the colostrum of dairy cows. Animal 7: 1824-1832.

Conneely, M., Berry, D.P., Murphy, J.P., Lorenz, I., Doherty, M.L. and Kennedy, E. 2014a. Effect of feeding colostrum at different volumes and subsequent number of transition milk feeds on the serum immunoglobulin $\mathrm{G}$ concentration and health status of dairy calves. Journal of Dairy Science 97: 6991-7000.

Conneely, M., Berry, D.P., Murphy, J.P., Lorenz, I., Doherty, M.L. and Kennedy, E. 2014b. Effects of milk feeding volume and frequency on body weight and health of dairy heifer calves. Livestock Science 161: 90-94.
Crossley, R.E., Bokkers, E.A.M., Browne, N., Sugrue, K., Kennedy, E., De Boer, I.J.M. and Conneely, M. 2021. Assessing dairy cow welfare during the grazing and housing periods on springcalving, pasture-based dairy farms. Journal of Animal Science 99: skab093.

Crump, A., Jenkins, K., Bethell, E.J., Ferris, C.P. and Arnott, G. 2019. Pasture access affects behavioural indicators of wellbeing in dairy cows. Animals 9: 902.

Crump, A., Jenkins, K., Bethell, E.J., Ferris, C.P., Kabboush, H., Weller, J. and Arnott, G. 2021. Optimism and pasture access in dairy cows. Scientific Reports 11: 1-11.

Cummins, C., Berry, D., Murphy, J., Lorenz, I. and Kennedy, E. 2017. The effect of colostrum storage conditions on dairy heifer calf serum immunoglobulin $\mathrm{G}$ concentration and preweaning health and growth rate. Journal of Dairy Science 100: 525-535.

da Costa, M.R., Fitzgerald, R.M., Manzanilla, E.G., O'Shea, H., Moriarty, J., McElroy, M.C. and Leonard, F.C. 2020. A crosssectional survey on respiratory disease in a cohort of Irish pig farms. Irish Veterinary Journal 73: 1-10.

da Costa, M.R., García Manzanilla, E., Diana, A., van Staaveren, N., Torres-Pitarch, A., Boyle, L.A. and Calderón Díaz, J.A. 2021. Identifying challenges to manage body weight variation in pig farms implementing all-in-all-out management practices and their possible implications for animal health: a case study. Porcine Health Management 7: 10.

DAFM. 2015. "Food Wise 2025. A Vision for Growth for the Irish Agricultural Economy for the Next 10 Years." Available online: https://www.gov.ie/en/publication/a6b0d-food-wise-2025/ [Accessed 29 March 2021], 102 pages.

DAFM. 2020. "National Pig Census 2020". Available online: https:// www.gov.ie/en/publication/5b140b-national-pig-census-2019/ [Accessed 31 March 2021].

DAFM. 2021. "Working Together for Animal Welfare. Ireland's Animal Welfare Strategy 2021-2025." Available online: https://www.gov. ie/en/publication/12d6a-animal-welfare-strategy/ [Accessed 08 March 2021], 27 pages.

D'Alessio, R., Hanlon, A. and O'Driscoll, K. 2021. Effect of feeder space on damaging behaviour in grower-finisher pigs. In preparation.

Dawkins, M.S., Donnelly, C.A. and Jones, T.A. 2004. Chicken welfare is influenced more by housing conditions than by stocking density. Nature 427: 342-344.

De Jong, I.C. and Gunnink, H. 2019. Effects of a commercial broiler enrichment programme with or without natural light on behaviour and other welfare indicators. Animal 13: 384-391.

De Vries, A. and Marcondes, M. 2020. Overview of factors affecting productive lifespan of dairy cows. Animal 14: s155-s164.

D'Eath, R.B., Arnott, G., Turner, S.P., Jensen, T., Lahrmann, H.P., Busch, M.E., Niemi, J.K., Lawrence, A.B. and Sandoe, P. 2014. Injurious tail biting in pigs: how can it be controlled in existing systems without tail docking? Animal 8: 1479-1497.

DeBoer, S.P., Garner, J.P., McCain, R.R., Lay Jr, D.C., Eicher, S.D. and Marchant-Forde, J.N. 2015. An initial investigation into the 
effects of isolation and enrichment on the welfare of laboratory pigs housed in the PigTurn ${ }^{\circledR}$ system, assessed using tear staining, behaviour, physiology and haematology. Animal Welfare 24: 15-27.

Dembele, I., Spinka, M., Stehulova, I., Panama, J. and Firla, P. 2006. Factors contributing to the incidence and prevalence of lameness on Czech dairy farms. Czech Journal of Animal Science 51: 102-109.

Diana, A., Manzanilla, E.G., Calderon Diaz, J.A., Leonard, F.C. and Boyle, L.A. 2017. Do weaner pigs need in-feed antibiotics to ensure good health and welfare? PLoS One 12: 10.

Diana, A., Boyle, L.A., Manzanilla, E.G., Leonard, F.C. and Calderon Díaz, J.A.C. 2019a. Ear, tail and skin lesions vary according to different production flows in a farrow-to-finish pig farm. Porcine Health Management 5: 19.

Diana, A., Boyle, L.A., Leonard, F.C., Carroll, C., Sheehan, E., Murphy, D. and Manzanilla, E.G. 2019b. Removing prophylactic antibiotics from pig feed: how does it affect their performance and health? BMC Veterinary Research 15: 67.

Diana, A., Snijders, S.E.M., Rieple, A. and Boyle, L.A. 2021. Why do Irish pig farmers use medications? Barriers for effective reduction of antimicrobials in Irish pig production. Irish Veterinary Journal 74: 12.

Dixon, L.M. 2020. Slow and steady wins the race: the behaviour and welfare of commercial faster growing broiler breeds compared to a commercial slower growing breed. PLoS One, 15: e0231006.

Drennan, M.J. and McGee, M. 2009. Performance of spring-calving beef suckler cows and their progeny to slaughter on intensive and extensive grassland management systems. Livestock Science 120: 1-12.

Earley, B. and Crowe, M.A. 2002. Effects of ketoprofen alone or in combination with local anesthesia during castration of bull calves on plasma haptoglobin, in vitro interferon-g production, white blood cell numbers and animal performance. Journal of Animal Science 80: 1044-1052.

Earley, B. and Murray, M. 2010. The effect of road and sea transport on inflammatory, adrenocortical, metabolic and behavioural responses of weanling heifers. BMC Veterinary Research 6: 36.

Earley, B. and O'Riordan, E.G. 2006. Effects on transporting bulls at different space allowances on physiological, haematological and immunological responses to a 12-h journey by road. Irish Journal of Agricultural and Food Research 45: 39-50.

Earley, B., Murray, M. and Prendiville, D.J. 2010. Effect of road transport for up to $24 \mathrm{~h}$ followed by twenty-four hour recovery on liveweight and physiological responses of bulls. BMC Veterinary Research 6: 38.

Earley, B., McDonnell, B., Murray, M., Prendiville, D.J. and Crowe, M.A. 2011. The effect of sea transport from Ireland to the Lebanon on inflammatory, adrenocortical, metabolic and behavioural responses of bulls. Research in Veterinary Science 91: 454-464.

Earley, B., Murray, M., Prendiville, D.J., Pintado, B., Borque, C. and Canali, E. 2012. The effect of transport by road and sea on physiology, immunity and behaviour of beef cattle. Research in Veterinary Science 92: 531-541.

Earley, B., Drennan, M. and O'Riordan, E.G. 2013. The effect of road transport in comparison to a novel environment on the physiological, metabolic and behavioural responses of bulls. Research in Veterinary Science 95: 811-818.

Earley, B., McNamara, J.D., Jerrams, S.J. and O'Riordan, E.G. 2017. Effect of concrete slats, three mat types and out-wintering pads on performance and welfare of finishing beef steers. Acta Veterinaria Scandinavica 59: S34.

Ebinghaus, A., Knierim, U., Simantke, C., Palme, R. and Ivemeyer, S. 2020. Fecal cortisol metabolites in dairy cows: a cross-sectional exploration of associations with animal, stockperson, and farm characteristics. Animals 10: 1787.

Ede, T., Lecorps, B., von Keyserlingk, M.A.G. and Weary, D.M. 2019. Symposium review: Scientific assessment of affective states in dairy cattle. Journal of Dairy Science 102: 10677-10694.

EFSA. 2006a. Basic Information for the development of the animal welfare risk assessment guidelines. EFSA/ AHAHW/2006/01.

EFSA. 2006b. "The Risks of Poor Welfare in Intensive Calf Farming Systems”. Available online: http://www.efsa.europa.eu/en/science/ ahaw/ahaw_opinions/1516.html [Accessed 31 March 2021].

EFSA. 2009. Scientific opinion on welfare of dairy cows in relation to metabolic and reproductive problems based on a risk assessment with special reference to the impact of housing, feeding, management and genetic selection. EFSA Journal 7: 1140.

EFSA. 2010. Scientific opinion on the influence of genetic parameters on the welfare and the resistance to stress of commercial broilers. EFSA Journal 8: 1666.

EFSA. 2012. Scientific opinion on the welfare of cattle kept for beef production and the welfare in intensive calf farming systems. EFSA Journal 10: 2669.

Elson, H.A. 2015. Poultry welfare in intensive and extensive production systems. World's Poultry Science Journal 71: 449-460.

Eurogroup for Animals. 2020. Available online: https://www. eurogroupforanimals.org/files/eurogroupforanimals/202011/2020_11_19_eurogroup_for_animals_broiler_report.pdf [Accessed 31 March 2021].

European Chicken Commitment. 2018. Available online: https:// welfarecommitments.com/europeletter/ [Accessed 31 March 2021].

European Commission (EU). 2001: White Paper on Food Safety (COM (1999) 719 final). Brussels: White Paper on Food Safety (COM (1999) 719 final). Brussels: Commission of the European Communities.

European Commission (EU). 2005. Council Regulation (EC) No 1/2005 of 22 December 2004 on the protection of animals during transport and related operations and amending Directive 64/442/ EEC and 93/119/EC and Regulation (EC) No 1255/97 (OJ L 3, 5.1.2005, p. 1).

European Commission (EU). 2008. Council Directive 2008/119/EC of 18 December 2008 laying down minimum standards for the protection of calves (OJ L 10, 15.1.2009, p. 7). 
European Commission. 2016a. Commission Recommendation (EU) 2016/336 of 8 March 2016 on the application of Council Directive 2008/120/EC laying down minimum standards for the protection of pigs as regards measures to reduce the need for tail docking.

European Commission. 2016b. Commission Staff Working Document on best practices with a view to the prevention of routine tail docking and the provision of enrichment materials to pigs, Accompanying the document Commission Recommendation on the application of Council Directive 2008/120/EC laying down minimum standards for the protection of pigs as regards measures to reduce the need for tail docking.

European Commission. 2016c. Attitudes of Europeans towards animal welfare. Special Eurobarometer Report 442.

European Commission. 2016d. Special Eurobarometer 442 Attitudes of Europeans towards Animal Welfare.

European Commission. 2020a. "Stepping up Europe's 2030 Climate Ambition - Investing in a Climate-Neutral Future for the Benefit of our People". Available online: https://eur-lex.europa.eu/legalcontent/EN/TXT/PDF/?uri=CELEX:52020DC0562\&from=EN [Accessed 29 March 2021], 25 pages.

European Commission. 2020b. "Farm to Fork Strategy — For a Fair, Healthy and Environmentally-Friendly Food System". Available online: https://ec.europa.eu/food/sites/food/files/safety/docs/f2f_ action-plan_2020_strategy-info_en.pdf [Accessed 29 March 2021], 22 pages.

European Chicken Commitment. 2018. Retrieved April 1, 2021. Available online: https://welfarecommitments.com/europeletter/ [Accessed 31 March 2021].

FAO. 2019. Food and Agriculture Organization of the United Nations. "FAOStat Database: Live Animals". Available online: http://www. fao.org/faostat/en/\#data [Accessed 31 March 2021].

Fernyhough, M., Nicol, C.J., van de Braak, T., Toscano, M.J. and Tønnessen, M. 2019. The ethics of laying hen genetics. Journal of Agricultural and Environmental Ethics 33: 15-36.

Fisher, A.D., Crowe, M.A., Prendiville, D.J. and Enright, W.J. 1997a. Indoor space allowance: effects on growth, behaviour, adrenal and immune responses of finishing beef heifers. Journal of Animal Science 64: 53-62.

Fisher, A.D., Crowe, M.A., O'Kiely, P. and Enright, W.J. 1997b. Growth, behaviour, adrenal and immune responses of finishing beef heifers housed on slatted floors at $1.5,2.0,2.5$ or $3.0 \mathrm{~m} 2$ space allowance. Livestock Production Science 51: 245-254.

Fontaneli, R.S., Sollenberger, L.E., Littell, R.C. and Staples, C.R. 2005. Performance of lactating dairy cows managed on pasturebased or in freestall barn-feeding systems. Journal of Dairy Science 88: 1264-1276.

Fraser, D. and Thompson, B.K. 1991. Armed sibling rivalry among suckling piglets. Behavioral Ecology and Sociobiology 29: 9-15.

Fraser, D., Weary, D.M., Pajor, E.A. and Milligan, B.N. 1997. A scientific conception of animal welfare that reflects ethical concerns. Animal Welfare 6: 187-204.
Gelsinger, S., Heinrichs, A. and Jones, C. 2016. A meta-analysis of the effects of pre-weaned calf nutrition and growth on first-lactation performance. Journal of Dairy Science 99: 6206-6214.

Gleerup, K.B., Andersen, P.H., Munksgaard, L. and Forkman, B. 2015. Pain evaluation in dairy cattle. Applied Animal Behaviour Science 171: 25-32.

Godden, S. 2008. Colostrum management for dairy calves. Veterinary Clinics of North America: Food Animal Practice 24: 19-39.

Graunke, K., Telezhenko, E., Hessle, A., Bergsten, C. and Loberg, J. 2011. Does rubber flooring improve welfare and production in growing bulls in fully slatted floor pens? Animal Welfare 20: 173-183.

Gupta, S., Earley, B. and Crowe, M.A. 2007. Pituitary, adrenal, immune and performance responses of mature Holstein $x$ Friesian bulls housed on slatted floors at various space allowances. Veterinary Journal 173: 594-604.

Haigh, A. and O'Driscoll, K. 2019. Irish pig farmer's perceptions and experiences of tail biting. Porcine Health Management 5: 30.

Haigh, A., Chou, J.-Y. and O'Driscoll, K. 2019. An investigation into the effectiveness of compressed straw blocks in reducing abnormal behaviour in growing pigs. Animal 13: 2576-2585.

Haley, D.B., Bailey, D.W. and Stookey, J.M. 2005. The effects of weaning beef calves in two stages on their behavior and growth rate. Journal of Animal Science 83: 2205-2214.

Harley, S., More, S., O'Connell, N., Hanlon, A., Teixeira, D. and Boyle, L. 2012. Evaluating the prevalence of tail biting and carcase condemnations in slaughter pigs in the republic and Northern Ireland, and the potential of abattoir meat inspection as a welfare surveillance tool. Veterinary Record 171: 621.

Harley, S., Boyle, L., O'Connell, N., More, S., Teixeira, D. and Hanlon, A. 2014. Docking the value of pigmeat? Prevalence and financial implications of welfare lesions in Irish slaughter pigs. Animal Welfare 23: 275-285.

Hartcher, K.M. and Lum, H.K. 2019. Genetic selection of broilers and welfare consequences: a review. World's Poultry Welfare Science Journal 76: 154-167.

Hartnett, P., Boyle, L.A, Younge, B. and O'Driscoll, K. 2019. The effect of group composition and mineral supplementation during rearing on measures of cartilage condition and bone mineral density in replacement gilts. Animals 9: 637 .

Hartnett, P., Boyle, L.A. and O'Driscoll, K. 2020a. The effect of group composition and mineral supplementation during rearing on the behavior and welfare of replacement gilts. Translational Animal Science 4: 1-13.

Hartnett, P., Boyle, L.A., O'Driscoll, K. 2020b. Rearing in female-only groups and dietary mineral supplementation improves sow welfare in the early parities, and lifetime performance. Translational Animal Science 4: 1-15.

Haskell, M.J. 2020. What to do with surplus dairy calves? Welfare, economic and ethical considerations. Landbauforschung $\mathbf{7 0}$ $45-48$.

Hemsworth, P. and Coleman, G. 2011. Human-livestock interactions: the stockperson and the productivity and welfare of intensively 
farmed animals. Human-animal interactions and animal productivity and welfare. Wallingford, UK, CABI, pages 47-83.

Hemsworth, P.H., Coleman, G.J., Barnett, J.L., Borg, S. and Dowling, S. 2002. The effects of cognitive behavioral intervention on the attitude and behavior of stockpersons and the behavior and productivity of commercial dairy cows. Journal of Animal Science 80: 68-78.

Hickey, M.C., Earley, B. and Fisher, A.D. 2003a. The effect of floor type and space allowance on welfare indicators of finishing steers. Irish Journal of Agricultural and Food Research 42: 89-100.

Hickey, M.C., Drennan, M. and Earley, B. 2003b. The effect of abrupt weaning of suckler calves on the plasma concentrations of cortisol, catecholamines, leukocytes, acute-phase proteins and in vitro interferon-gamma production. Journal of Animal Science 81: 2847-2855.

Johnsen, J.F., Johanssen, J.R.E., Aaby, A.V., Kischel, S.G., Ruud, L.E., Soki-Makilutila, A., Kristiansen, T.B., Wibe, A.G., Bøe, K.E. and Ferneborg, S. 2021. Investigating cow-calf contact in cowdriven systems: behaviour of the dairy cow and calf. Journal of Dairy Research 88: 52-55.

Keane, M.G. 1999. Effects of time of complete or split castration on performance of beef cattle. Irish Journal of Agricultural and Food Research 38: 41-51.

Keane, M.G. 2003. Beef production from Holstein-Friesian bulls and steers of New Zealand and European-American descent, and Belgian Blue $\times$ Holstein-Friesians, slaughtered at two weights. Livestock Production Science 84: 207-218.

Keane, M.G. 2010. A comparison of finishing strategies to fixed slaughter weight for Holstein Friesian and Belgian Blue $\times$ Holstein Friesian steers. Irish Journal of Agricultural and Food Research 49: 41-54.

Keane, M.G. and Allen, P. 1998. Effects of production system intensity on performance, carcass composition and meat quality of beef cattle. Livestock Production Science 56: 203-214.

Keane, M.P, McGee, M., O'Riordan, E.G., Kelly, A.K. and Earley, B. 2015. Effect of floor type on hoof lesions, dirt scores, immune response and production of beef bulls. Livestock Science 180: 220-225.

Keane, M.P., McGee, M., O'Riordan, E.G., Kelly, A.P. and Earley, B. 2017. Effect of space allowance and floor type on performance and welfare of finishing beef heifers. Animal 11: 2285-2294.

Kelly, P., Shalloo, L., Wallace, M. and Dillon, P. 2020. The Irish dairy industry - recent history and strategy, current state and future challenges. International Journal of Dairy Technology 73: 309-323.

Kennedy, E., O'Donovan, M., Murphy, J.P. and O'Mara, F. 2005. Effects of grass pasture and concentrate-based feeding systems for spring-calving dairy cows in early spring on performance during lactation. Grass Forage Science 60: 310-318.

Kennedy, A.E., O'Doherty, E.F., Byrne, N., O'Mahony, J., Kennedy, E.M. and Sayers, R.G. 2014. A survey of management practices on Irish dairy farms with emphasis on risk factors for Johne's disease transmission. Irish Veterinary Journal 67: 27-38.
Kenny, F.J. and Tarrant, P.V. 1987. The reaction of young bulls to short-haul road transport. Applied Animal Behaviour Science 17: 209-227.

Kinane, O. 2020. Investigating the effects of free lactation crates on sow and piglet welfare. MSc thesis, University College Cork.

Kinane, O., Butler, F. and O'Driscoll, K. 2021. Freedom to grow: improving sow welfare also benefits piglets. Animals 11: 1181.

Kremer, L., Klein Holkenborg, S.E.J., Reimert, I., Bolhuis, J.E. and Webb, L.E. 2020. The nuts and bolts of animal emotion. Neuroscience and Biobehavioral Reviews 113: 273-286.

Krohn, C.C. 1994. Behaviour of dairy cows kept in extensive (loose housing/pasture) or intensive (tie stall) environments. III. Grooming, exploration and abnormal behaviour. Applied Animal Behaviour Science 42: 73-86.

Lawrence, A.B., Vigors, B. and Sandøe, P. 2019. What is so positive about positive animal welfare?-a critical review of the literature. Animals 9: 783.

Legrand, A.L., von Keyserlingk, M.A.G. and Weary, D.M. 2009. Preference and usage of pasture versus free-stall housing by lactating dairy cattle. Journal of Dairy Science 92: 3651-3658.

Leonard, F.C., O' Connell, J. and O' Farrell, K. 1994. Effect of different housing conditions on behavior and foot lesions in Friesian heifers. Veterinary Record 134: 490-494.

Leonard, F.C., O'Connell, J.M. and Lynch, P.B. 1996a. Skin and foot lesions in sows and piglets on different farrowing house floor types. Irish Journal of Agricultural and Food Research 35: 67.

Leonard, F.C., O'Connell, J.M. and O'Farrell, K.J. 1996b. Effect of overcrowding on claw health in first-calved Friesian heifers. British Veterinary Journal 152: 459-472.

Leruste, H., Brscic, M., Cozzi, G., Kemp, B., Wolthuis-Fillerup, M., Lensink, B., Bokkers, E. and Van Reenen, C. 2014. Prevalence and potential influencing factors of non-nutritive oral behaviours of veal calves on commercial farms. Journal of Dairy Science 97: 7021-7030.

Lewis, E., Boyle, L.A., Brophy, P., O'Doherty, J.V. and Lynch, P.B. 2005a. The effect of two piglet teeth resection procedures on the welfare of piglets in farrowing crates. Part 1. Applied Animal Behaviour Science 90: 233-249.

Lewis, E., Boyle, L.A., Brophy, P., O'Doherty, J.V. and Lynch, P.B. $2005 \mathrm{~b}$. The effect of two piglet teeth resection procedures on the welfare of sows in farrowing crates. Part 2. Applied Animal Behaviour Science 90: 251-264.

Lewis, E., Boyle, L.A., Lynch, P.B., Brophy, P. and O'Doherty, J.V. 2005c. The effect of floor type in farrowing crates on piglet welfare. Irish Journal of Agriculture and Food Research 44: 69-81.

Lewis, E., Boyle, L.A., Brophy, P., O'Doherty, J.V. and Lynch, P.B. 2006. The effect of providing shredded paper or ropes to piglets in farrowing crates on their behaviour and health and the behaviour and health of their dams. Applied Animal Behaviour Science 96: 1-17.

Llamas Moya, S., Boyle, L.A., Lynch, P.B. and Arkins, S. 2006a. Effects of surgical castration on the behavioural and physiological responses of newly-weaned pigs. Acta Veterinaria Scandinavica 48: 4. 
Llamas Moya, S., Boyle, L.A., Lynch, P.B. and Arkins, S. 2006b. Influence of teeth resection on the skin temperature and acute phase response in newborn piglets. Animal Welfare 15: 291-297.

Llamas Moya, S., Alonso Gómez, M., Boyle, L.A., Mee, J.F., O'Brien, B. and Arkins, S. 2008a. Effects of milking frequency on phagocytosis and oxidative burst activity of phagocytes from primiparous and multiparous dairy cows during early lactation. Journal of Dairy Science 91: 587-595.

Llamas Moya, S., Boyle, L.A., Lynch, P.B. and Arkins, S. 2008b. Effect of surgical castration on the behavioural and acute phase responses of 5-day-old piglets. Applied Animal Behaviour Science 111: 133-145.

Llamas Moya, S., Boyle, L.A., Lynch, P.B. and Arkins, S. $2008 \mathrm{c}$. Surgical castration of pigs affects the behavioural response to a low-dose lipopolysaccharide (LPS) challenge after weaning. Applied Animal Behaviour Science 112: 40-57.

Lorenz, I. 2021. Calf health from birth to weaning - an update. Irish Veterinary Journal 74: 5.

Lorenz, I., Mee, J.F., Earley, B. and More, S.J. 2011. Calf health from birth to weaning. I. General aspects of disease prevention. Irish Veterinary Journal 64: 10-11.

Lowe, D.E., Steen, R.W.J., Beattie, V.E. and Moss, B.W. 2001a. The effects of floor type systems on the performance, cleanliness, carcass composition and meat quality of housed finishing beef cattle. Livestock Production Science 69: 33-42.

Lowe, D.E., Steen, R.W.J. and Beattie, V.E. 2001b. Preferences of housed finishing beef cattle for different floor types. Animal Welfare 10: 395-404.

Lynch, E.M., Earley, B., McGee, M. and Doyle, S. 2010a. Effect of abrupt weaning at housing on leukocyte distribution, functional activity of neutrophils, and acute phase protein response of beef calves. BMC Veterinary Research 6: 39.

Lynch, E.M., Earley, B., McGee, M. and Doyle, S. $2010 \mathrm{~b}$. Characterisation of physiological and immunological responses in beef cows to abrupt weaning and subsequent housing. BMC Veterinary Research 6: 37.

Lynch, E.M., McGee, M., Doyle, S. and Earley, B. 2011. Effect of post-weaning management practices on physiological and immunological responses of weaned beef calves. Irish Journal of Agricultural and Food Research 50: 161-174.

Lynch, E.M., McGee, M., Doyle, S. and Earley, B. 2012. Effect of preweaning concentrate supplementation on peripheral distribution of leukocytes, functional activity of neutrophils, acute phase protein and behavioural responses of abruptly weaned and housed beef calves. BMC Veterinary Research 8: 1.

Marquou, S., Blouin, L., Djakite, H., Laplante, R. and Buczinski, S. 2019. Health parameters and their association with price in young calves sold at auction for veal operations in Québec. Canadian Journal Dairy Science 102: 6454-6465.

Maton, A., Daelemans, J. and Lambrecht, J. 2012. "Housing of Animals: Construction and Equipment of Animal Houses”. Elsevier Science Publishers, Amsterdam, The Netherlands.
Mattiello, S., Battini, M., De Rosa, G., Napolitano, F. and Dwyer, C. 2019. How can we assess positive welfare in ruminants? Animals 9: 758.

Mazurek, M., Prendiville, D.J., Crowe, M.A., Veissier, I. and Earley, B. 2010. An on-farm investigation of beef suckler herds using an animal welfare index (AWI). BMC Veterinary Research 6: 55.

McLean, J.A., Savory, C.J. and Sparks, N.H.C. 2002. Welfare of male and female broiler chickens in relation to stocking density, as indicated by performance, health and behaviour. Animal Welfare 11: 55-73.

Mee, J.F. 2020. Denormalizing poor dairy youngstock management: dealing with "farm-blindness". Journal of Animal Science 98: S140-S149.

Mee, J.F. and Boyle, L.A. 2020. Assessing whether dairy cow welfare is "better" in pasture-based than in confinement-based management systems. New Zealand Veterinary Journal 68: 168-177.

Mee, J.F., Barrett, D., Silva Boloña, P., Conneely, M., Earley, B., Fagan, S., Keane, O.M. and Lane, E.A. 2022. Ruminant health research - progress to date and future prospects, with an emphasis on Irish research. Irish Journal of Agricultural and Food Research 61: in press.

Mellor, D.J. 2016. Updating animal welfare thinking: moving beyond the "five freedoms" towards "a life worth living". Animals 6: 21.

Mellor, D.J. and Beausoleil, N.J. 2015. Extending the 'five domains' model for animal welfare assessment to incorporate positive welfare states. Animal Welfare 24: 241-253.

Mendl, M. and Paul, E.S. 2020. Animal affect and decision-making. Neuroscience \& Biobehavioral Reviews 112: 144-163.

Mendl, M., Burman, O.H.P., Parker, R.M. and Paul, E.S. 2009. Cognitive bias as an indicator of animal emotion and welfare: emerging evidence and underlying mechanisms. Applied Animal Behaviour Science 118: 161-181.

Mendl, M., Burman, O.H.P. and Paul, E.S. 2010. An integrative and functional framework for the study of animal emotion and mood. Proceedings in Biological Science 277: 2895-2904.

Miller-Cushon, E.K., Bergeron, R., Leslie, K.E. and DeVries, T.J. 2013. Effect of milk feeding level on development of feeding behaviour in dairy calves. Journal of Dairy Science 96: 551-564.

Misra, S., Bokkers, E., Quinn, A., Upton, J., de Boer, I.J.M. and O'Driscoll, K. 2021. Effect of environmental enrichment and group size on the water use and waste in grower-finisher pigs. Scientific Reports 11: 16380.

Nalon, E. and De Briyne, N. 2019. Efforts to ban the routine tail docking of pigs and to give pigs enrichment materials via EU law: where do we stand a quarter of a century on? Animals 9: 132.

Newberry, R.C. and Swanson, J.C. 2008. Implications of breaking mother-young social bonds. Applied Animal Behaviour Science 110: 3-23.

Norring, M., Kaukonen, E. and Valros, A. 2016. The use of perches and platforms by broiler chickens. Applied Animal Behaviour Science 184: 91-96.

O'Connell, N.E. 2007. Influence of access to grass silage on the welfare of sows introduced to a large dynamic group. Applied Animal Behaviour Science 107: 45-57. 
O'Connell, J.M., Leonard, F.C. and Lynch, P.B. 1996. Effect of floor type on the behavioural activity of sows in the farrowing house. Irish Journal of Agricultural and Food Research 35: 66.

O'Connell, N.E., Beattie, V.E. and Moss, B.W. 2003. Influence of social status on the welfare of sows in static and dynamic groups. Animal Welfare 12: 239-249.

O'Connell, N.E., Beattie, V.E. and Moss, B.W. 2004. Influence of replacement rate on the welfare of sows introduced to a large dynamic group. Applied Animal Behaviour Science 85: 43-56.

O'Driscoll, K. and Schmitt, O. 2016. "Giving Piglets the Best Start in Life". Teagasc Pig Newsletter October 2016. Available online: https://www.teagasc.ie/media/website/publications/2016/Teagasc_ Pig_Newsletter-October_2016.pdf [Accessed 21 September 2021].

O'Driscoll, K., Boyle, L., French, P. and Hanlon, A. 2008a. The effect of out-wintering pad design on hoof health and locomotion score of dairy cows. Journal of Dairy Science 91: 544-553.

O'Driscoll, K., Boyle, L., French, P., Meaney, B. and Hanlon, A. 2008b. The effect of out-wintering pad design on dirtiness score, somatic cell score and mastitis incidence in dairy cows. Animal 2: 912-920.

O'Driscoll, K., Hanlon, A. and Boyle, L. 2008c. The effect of outwintering pad design on the synchrony of dairy cow behavior. Journal of Dairy Science 91: 4651-4660.

O'Driscoll, K., Gleeson, D., O'Brien, B. and Boyle, L. 2010. Effect of milking frequency and nutritional level on hoof health, locomotion score and lying behaviour of dairy cows. Livestock Science 127: 248-256.

O'Driscoll, K., Gleeson, D., O'Brien, B. and Boyle, L. 2011. Does omission of a regular milking event affect cow comfort? Livestock Science 138: 132-143.

O'Driscoll, K., O'Gorman, D., Taylor, S. and Boyle, L.A. 2013a. The influence of a magnesium rich marine extract on behaviour, salivary cortisol levels, and skin lesions in growing pigs. Animal 7: 1017-1027.

O'Driscoll, K., Lemos Teixeira, D., O'Gorman, D., Taylor, S. and Boyle, L.A. 2013b. The influence of a magnesium rich marine supplement on behaviour, salivary cortisol levels, and skin lesions in growing pigs exposed to acute stressors. Applied Animal Behaviour Science 145: 92-101.

O'Driscoll, K., Lewis, E. and Kennedy, E. 2015. Effect of feed allowance at pasture on lying behaviour and locomotory ability of dairy cows. Applied Animal Behaviour Science 166: 25-34.

O'Driscoll, K., Lewis, E. and Kennedy, E. 2019. Effect of feed allowance at pasture on the lying behaviour of dairy cows. Applied Animal Behaviour Science 213: 40-46.

OECD. 2020. "OECD Study on the World Organisation for Animal Health (OIE) Observatory: Strengthening the Implementation of International Standards". OECD Publishing, Paris, https://doi. org/10.1787/c88edbcd-en.OIE. Available online: https://www.oie. int/fileadmin/Home/eng/Health_standards/tahc/current/chapitre_ aw_beef_catthe.pdf [Accessed 3 May 2021], 10 pages.

Olmos, G., Boyle, L., Hanlon, A., Patton, J., Murphy, J.J. and Mee, J.F. 2009a. Hoof disorders, locomotion ability and lying times of cubicle-housed compared to pasture-based dairy cows. Livestock Science 125: 199-207.
Olmos, G., Mee, J.F., Hanlon, A., Patton, J., Murphy and Boyle, L. 2009b. Peri-partum health and welfare of Holstein-Friesian cows in a confinement-TMR system compared to a pasture-based system. Animal Welfare 18: 467-476.

O'Loughlin, A., McGee, M., Waters, S.M., Doyle, S. and Earley, B. 2011. Examination of the bovine leukocyte environment using immunogenetic biomarkers to assess immunocompetence following exposure to weaning stress. BMC Veterinary Research 7: 45.

O'Loughlin, A., Lynn, D.J., McGee, M., Doyle, S., McCabe, M. and Earley, B. 2012. Transcriptomic analysis of the stress response to weaning at housing in bovine leukocytes using RNA-seq technology. BMC Genomics 13: 250.

O'Loughlin, A., McGee, M., Doyle, S. and Earley, B. 2014. Biomarker responses to weaning stress in beef calves. Research in Veterinary Science 97: 458-463.

Osawe, W., Laepple, D., Hanlon, A. and Boyle, L.A. 2021. Calf welfare post EU milk quota abolition: exploring farmers' attitudes and determinants of calf welfare indicators. Journal of Dairy Science 104: 9967-9980.

O'Sullivan, M., Butler, S.T., Pierce, K.M., O'Sullivan, K., Crowe, M. and Buckley, F. 2020. Reproductive efficiency and survival of Holstein-Friesian cows of divergent Economic Breeding Index, evaluated under seasonal calving pasture-based management Journal of Dairy Science 103: 1685-1700.

García Pinillos, R., Appleby, M.C., Manteca, X., Scott-Park, F., Smith, C. and Velarde, A. 2016. One welfare-a platform for improving human and animal welfare. Veterinary Record 179: 412-413.

Price, E.O., Harris, J.E., Borgwardt, R.E., Sween, M.L. and Connor, J.M. 2003. Fenceline contact of beef calves with their dams at weaning reduces the negative effects of separation on behaviour and growth rate. Journal of Animal Science 81: 116-121.

Quinn, A.J. 2014. The prevalence and risk factors for lameness, limb lesions and claw lesions in pigs, and the influence of gilt nutrition on indicators of limb health. PhD thesis, University of Warwick, UK.

Quinn, A.J., Boyle, L.A. and Green, L.E. 2015. A cross-sectional study on the prevalence and risk factors for foot and limb lesions in piglets on commercial farms in Ireland. Preventative Veterinary Medicine 119: 162-171.

Rayner, A.C., Gill, R., Brass, D., Willings, T.H. and Bright, A. 2016. Smothering in UK free-range flocks. Part 2: investigating correlations between disease, housing and management practices. Veterinary Record 179: 252.

Rayner, A.C., Newberry, R.C., Vas, J. and Mullan, S. 2020. Slowgrowing broilers are healthier and express more behavioural indicators of positive welfare. Scientific Reports 10: 1-14.

Read, E., Baxter, E.M., Farish, M. and D'Eath, R.B. 2020. Trough half empty: pregnant sows are fed under half of their ad libitum intake. Animal Welfare 29: 151-162.

Riber, A.B., Van de Weerd, H.A., De Jong, I.C. and Steenfeldt, S. 2018. Review of environmental enrichment for broiler chickens. Poultry Science 97: 378-396.

Roche, J.R., Dennis, N.A., Macdonald, K.A., Phyn, C.V.C., Amer, P.R., White, R.R. and Drackley, J.K., 2015. Growth targets and rearing 
strategies for replacement heifers in pasture-based systems: a review. Animal Production Science 55: 902-915.

Roche, J.R., Berry, D.P., Bryant, A.M., Burke, C.R., Butler, S.T., Dillon, P.G., Donaghy, D.J., Horan, B., Macdonald, K.A. and Macmillan, K.L. 2017. A 100-year review: a century of change in temperate grazing dairy systems. Journal of Dairy Science 100: 10189-10233.

Schwean-Lardner, K., Fancher, B.I. and Classen, H.L. 2012. Impact of day length on behavioural output in commercial broilers. Applied Animal Behaviour Science 137: 43-52.

Schwean-Lardner, K., Fancher, B.I., Gomis, S., Van Kessel, A., Dalal, S. and Classen, H.L. 2013. Effect of day length on cause of mortality, leg health and ocular health in broilers. Poultry Science 92: 1-11.

Scientific Committee on Animal Health and Animal Welfare. (SCAHAW). 2001. The welfare of cattle kept for beef production. In: "European Commission, Health \& Consumer Protection Directorate-General, SANCO.C.2/AH/R22/2000". Available online: https://ec.europa.eu/food/sites/food/files/safety/docs/sci-com_ scah_out54_en.pdf [Accessed 31 March 2021].

Simonin, D. and Gavinelli, A. 2019. The European Union legislation on animal welfare: state of play, enforcement and future activities [PDF file]. In: "Animal Welfare: From Science to Law" (eds. S. Hild and L. Schweitzer), pages 59-70.

Sinclair, A.R.L., D'Eath, R.B., Brunton, P.J., Prunier, A. and Sandercock, D. 2018. Traumatic tooth shortening in commercial piglets: effects on gross tooth pathology and mRNA markers of inflammation and pain. Proceedings of the International Association for the Study of Pain (IASP) 17th World Congress on Pain, 12-15 September 2018.

Sinnott, A.M., Kennedy, E., and Bokkers, E.A.M. 2021. The effects of manual and automated milk feeding methods on group-housed calf health, behaviour, growth and labour. Livestock Science 244: 104343.

Sirovnik, J., Barth, K., de Oliveira, D., Ferneborg, S., Haskell, M.J., Hillmann, E., Jensen, M.B., Mejdell, C.M., Napolitano, F. and Vaarst, M. 2020. Methodological terminology and definitions for research and discussion of cow-calf contact systems. Journal of Dairy Research 87: 108-114.

Soberon, F., Raffrenato, E., Everett, R.W. and Van Amburgh, M.E. 2012. Pre-weaning milk replacer intake and effects on long-term productivity of dairy calves. Journal of Dairy Science 95: 783-793.

Stewart, C.L., O'Connell, N.E. and Boyle, L.A. 2008. Influence of access to straw provided in racks on the welfare of sows in large dynamic groups. Applied Animal Behaviour Science 112: 235-247.

Stewart, C.L., Boyle, L.A., McCann, M.E.E. and O'Connell, N.E. 2010. The effect of feeding a high fibre diet on the welfare of sows housed in large dynamic groups. Animal Welfare 19: 349-357.

Stewart, C.L., Boyle, L.A. and O'Connell, N.E. 2011. The effect of increasing dietary fibre and the provision of straw racks on the welfare of sows housed in small static groups. Animal Welfare 20: 633-640.

Stilwell, G., Schubert, H. and Broom, D.M. 2014. Short communication: Effects of analgesic use post-calving on cow welfare and production. Journal of Dairy Science 97: 888-891.
Stilwell, G.T., Ferrador, A.M., Santos, M.S., Domingues, J.M. and Carolino, N. 2019. Use of topical local anesthetics to control pain during treatment of hoof lesions in dairy cows. Journal of Dairy Science 102: 6383-6390.

Stookey, J.M., SchwartzkopfGenswein, K.S., Waltz, C.S. and Watts, J.M. 1997. Effects of remote and contact weaning on behaviour and weight gain of beef calves. Journal of Animal Science 75(Suppl 1):157(Abstr.).

Sutherland, M.A., Worth, G.M., Schütz, K.E. and Stewart, M. 2014. Rearing substrate and space allowance influences locomotor play behaviour of dairy calves in an arena test. Applied Animal Behaviour Science 154: 8-14.

Teixeira, D.L. and Boyle, L.A. 2014. A comparison of the impact of behaviours performed by entire male and female pigs prior to slaughter on skin lesion scores of the carcass. Livestock Production Science 170: 142-149.

Ting, S.T.L, Earley, B., Veissier, I., Gupta, S. and Crowe, M.A. 2005. Effects of age of Holstein-Friesian calves on plasma cortisol, acutephase proteins, immunological function, scrotal measurements and growth in response to Burdizzo castration. Animal Science 80: 377-386.

Tuyttens, F.A.M. 2005. The importance of straw for pig and cattle welfare: a review. Applied Animal Behaviour Science 92: 261-282.

Valros, A.E. 2018. Tail biting. In: "Advances in Pig Welfare", Woodhead Publishing Series in Food Science, Technology and Nutrition Chapter 5, Woodhead publishing (978-0-08-101012-9). pages 137-166.

Van Staaveren, N., Teixeira, D.L., Hanlon, A. and Boyle, L.A. 2015. The effect of mixing entire male pigs prior to transport to slaughter on behaviour, welfare and carcass lesions. PLos One 10: 1-15.

van Staaveren, N., Doyle, B., Manzanilla, E.G., Calderón-Díaz, J.A., Hanlon, A. and Boyle, L. 2017. Validation of carcass lesions as indicators for on-farm health and welfare of pigs. Journal of Animal Science 95: 1528-1536.

van Staaveren, N., Calderón-Díaz, J.A., Manzanilla, E.G., Hanlon, A and Boyle, L. 2018. Prevalence of health and welfare outcomes in the weaner and finisher stages of the production cycle on 31 Irish pig farms. Irish Veterinary Journal 71: 9.

Velarde, A. and Dalmau, A. 2012. Animal welfare assessment at slaughter in Europe: moving from inputs to outputs. Meat Science 92: 244-251.

von Keyserlingk, M.A.G., Rushen, J., de Passille, A.M. and Weary, D.M. 2009. The welfare of dairy cattle - key concepts and the role of science. Journal of Dairy Science 92: 4101-4111.

Weary, D.M., Niel, L., Flower, F.C. and Fraser, D. 2006. Identifying and preventing pain in animals. Applied Animal Behaviour Science 100: 64-76.

Webb, L.E., Bokkers, E.A.M., Heutinck, L.F.M., Engel, B., Buist, W.G., Rodenburg, T.B., Stockhofe-Zurwieden, N. and Van Reenen, C.G. 2013. Effects of roughage source, amount, and particle size on behaviour and gastrointestinal health of veal calves. Journal of Dairy Science 96: 7765-7776. 
Webster, J.R., Schütz, K.E., Sutherland, M.A., Stewart, M. and Mellor, D.J. 2015. Different animal welfare orientations towards some key research areas of current relevance to pastoral dairy farming in New Zealand. New Zealand Veterinary Journal 63: 31-36.

Wechsler, B. 2005. An authorisation procedure for mass-produced farm animal housing systems with regard to animal welfare. Livestock Production Science 94: 71-79.

Wechsler, B. 2011. Floor quality and space allowance in intensive beef production: a review. Animal Welfare 20: 497-503.

Weeks, C.A., Danbury, T.D., Davies, H.C., Hunt, P. and Kestin, S.C. 2000. The behaviour of broiler chickens and its modification by lameness. Applied Animal Behaviour Science 67: 111-125.

Weeks, C.A., Lambton, S.L. and Williams, A.G. 2016. Implications for welfare, productivity and sustainability of the variation in reported levels of mortality for laying hen flocks kept in different housing systems: a meta-analysis of ten studies. PLos One 11: e0146394.

Welfare Quality. 2009. "Welfare Quality ${ }^{\circledR}$ Assessment Protocol for Cattle". Welfare Quality Consortium, Lelystad, The Netherlands.
Available online: https://edepot.wur.nl/233467 [ Accessed 6 May 2021].

Wenker, M.L., Bokkers, E.A.M., Lecorps, B., von Keyserlingk, M.A.G., van Reenen, C.G., Verwer, C.M., and Weary, D.M. 2020. Effect of cow-calf contact on cow motivation to reunite with their calf. Scientific Reports 10: 1-5.

Whay, H.R., Main, D.C.J, Green, L.E. and Webster, A.J.F. 2003. Assessment of the welfare of dairy cattle using animal-based measurements: direct observations and investigation of farm records. Veterinary Record 153: 197202.

Wilkinson, M. 1998. "Straw in Europe". Chalcombe Publications, Southampton, UK.

Wolf, C.A., Tonsor, G.T., McKendree, M.G.S., Thomson, D.U. and Swanson, J.C. 2016. Public and farmer perceptions of dairy cattle welfare in the United States. Journal of Dairy Science 99: 5892-5903.

Yeates, J.W. and Main, D.C. 2008. Assessment of positive welfare: a review. The Veterinary Journal 175: 293-300. 